\title{
THE FORMATION AND FAILURE OF NATURAL DAMS
}

By John E. Costa and Robert L. Schuster

US GEOLOGICAL SURVEY

Open-File Report 87-392 
DEPARTMENT OF THE INTERIOR

DONALD PAUL HODEL, Secretary

U.S. GEOLOGICAL SURVEY

Dallas L. Peck, Director

For additional information write to:

Chief of Research U.S. Geological Survey Cascades Volcano Observatory 5400 MacArthur Blvd.

Vancouver, Washington 98661
Copies of this report can be purchased from:

U.S. Geological Survey Books and Open-File Reports Section Box 25425

Federal Center

Denver, CO 80225 


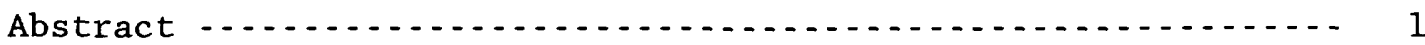

Introduction

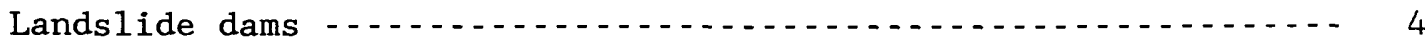

Geomorphic settings of landslide dams -............... 4

Types of mass movements that form landslide dams -...... 4

Causes of dam-forming landslides -

Classification of landslide dams - . .

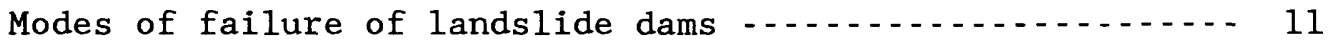

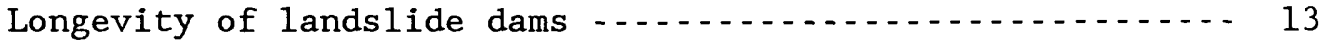

Physical measures to improve the stability of

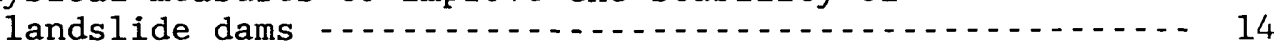

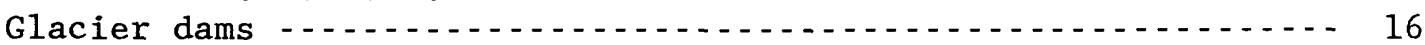

Geomorphic settings of ice dams $\ldots \ldots \ldots$

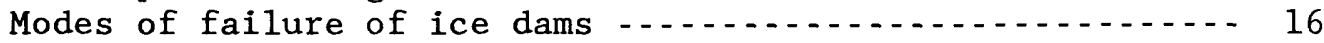

Longevity and controls of glacier dams $\ldots \ldots$

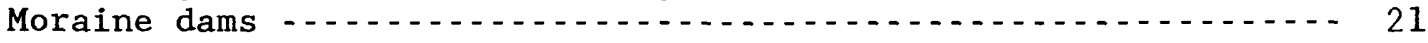

Geomorphic settings of moraine dams .................. 21

Modes of failure of moraine dams _..................... 22

Longevity and controls of moraine dams _.............. 25

Floods from the failure of natural dams

Comparison of floods from the failure of different

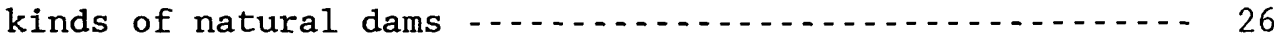

Prediction and reconstruction of floods from dam

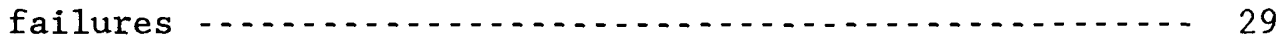

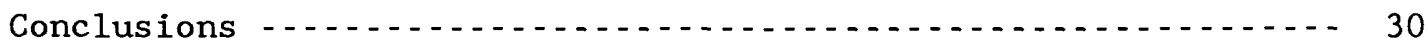

References -..... 


\section{ILLUSTRATIONS}

Page

Figure 1. Graph showing distribution of landslide dams by type of landslide, based Ion 183 cases from the literature and the authors' experience .... 5

2. Graph showing causes of landslides that have formed dams, based on 128 cases from the literature and the authors' experience ...... 8

3. Diagrams showing classification of landslide

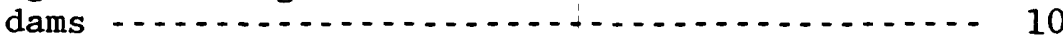

4. Photograph view upstream along the Min River, Sichuan Province, Peoples Republic of China, showing remains of the 1933 earthquake -

induced Yinping landslide dam .............

5. Graph showing modes of failure of landslide dams, based on 55 failures from the literature and the authors experience ...... 12

6. Graph showing length of time before failure of landslide dams, based on 73 cases from the literature and the authors' experience .... 13

7. Photograph of the landslide dam formed by the 1959 Madison Canyon landslide, Montana ....... 15

8. Photograph of a glacier-dammed lake in a tributary valley (type D, table 4), Coast

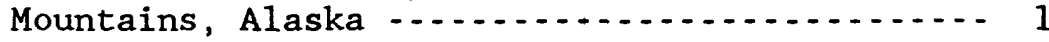

9. Diagram showing classification of glacial-ice

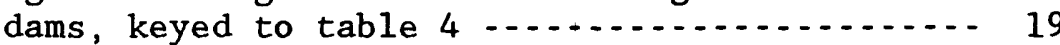

10-A. Photograph of Nostetuko Lake, a neoglacial moraine-dammed lake, and Cumberland Glacier, British Columbia, Canada, in July $1977 \ldots \ldots 24$

10-B. Photograph of Nostetuko Lake and Cumberland Glacier, British Columbia, Canada, in August 1983, after failure of the moraine

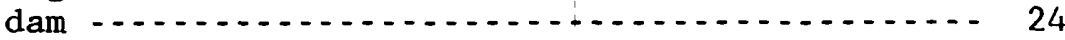

11. Photograph of the 1983 landslide at Thistle, Utah, and its temporary impoundment, Thistle Lake, September 1983 
12. Graph showing dam factor (as a surrogate for potential energy) versus peak discharge for various types of dam failures .............

13. Diagram showing cross section of Mayunmarca landslide dam, Peru, and Nostetuko moraine dam, British Columbia, compared to the maximum cross section of a large earth-fill dam at Oroville, California

\section{TABLES}

Page

Table

1. Types of obstructive natural dams ........... 3

2. We11-documented examples of landslide dams formed by specific classes of landslides ..... 6

3. We11-documented examples of glacial-ice dams that have failed and produced jokulhlaups .....

4. Classification of ice-dammed lakes _......... 18

5. We1l-documented examples of moraine dams that

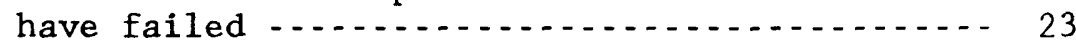

6. Summary of regression equations to predict peak discharge from the failure of earthand rock-fill, moraine, glacial-ice, and

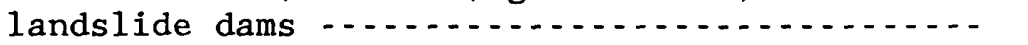


John E. Costa and Robert L. Schuster

"In the Oisans, Western Alps, a (land)slip in 1181 made a lake ten kilometers long, known as Lac de St. Laurent, and the farmers of the valley became fishermen...." (Davis, 1882; p. 370-371).

\section{ABSTRACT}

Of the numerous kinds of dams that form by natural processes, dams formed from landslides, glacial ice, and neoglacial moraines present the greatest threat to people and property. Landslide dams form in a wide range of physiographic settings. The most common types of mass movements that form landslide dams are rock and debris avalanches, rock and soil slumps and slides, and mud, debris, and earth flows. The most common initiation mechanisms for dam-forming landslides are excessive rainfall and snowmelt and earthquakes.

Landslide dams can be classified into six categories based on their relation with the valley floor. Type I dams (11 percent of the 81 landslide dams around the world that we were able to classify) do not reach from one valley side to the other. Type II dams (44 percent) span the entire valley flood, occasionally depositing material high up on opposite valley sides. Type III dams (41 percent) move considerable distances both upstream and downstream from the landslide failure. Type IV dams ( 1 percent) are rare and involve the contemporaneous failure of material from both sides of a valley. Type $V$ dams ( 1 percent) also are rare and are created when a single landslide sends multiple tongues of debris into a valley and forms two or more landslide dams in the same reach of river. Type VI dams ( 3 percent) involve one or more failure surfaces that extend under the stream or valley and emerge on the opposite valley side.

Many landslide dams fail shortly after formation. In our sample of 73 documented landslide-dam failures, 27 percent of the landslide dams failed less than 1 day after formation, and about 50 percent failed within 10 days. Overtopping is by far the most common cause of failure. The timing of failure and the magnitude of the resulting floods are controlled by dam size and geometry, material characteristics of the blockage, rate of inflow to the impoundment, size and depth of the impoundment, bedrock control of flow, and engineering controls such as artificial spillways, diversions, tunnels, and planned breaching by blasting or conventional excavation.

Glacial-ice dams can produce at least nine kinds of ice-dammed lakes. The most dangerous are lakes formed in main valleys dammed by tributary glaciers. Failure can occur by erosion of a drainage tunnel under or through the ice dam or by a channel over the ice dam. Cold polar-ice dams generally drain supraglacially or marginally by downmelting of an outlet channel. Warmer temperate-ice dams tend to fail by sudden englacial or subglacial breaching and drainage. 
Late-neoglacial moraine-dammed lakes are located in steep mountain areas affected by the advances and retreats of valley glaciers in the last several centuries. These late-neoglacial dams pose hazards because (1) they are sufficiently young that vegetation has not stabilized their slopes, (2) many dam faces are steeper than the angle of repose, (3) these dams and lakes are immediately downslope from steep crevassed glaciers and near-vertical rock slopes, and (4) downstream from these dams are steep canyons with easily erodible materials that can be incorporated into the flow and increase flood peaks. The most common reported failure mechanism is overtopping and breaching by a wave or series of waves in the lake, generated by icefalls, rockfalls, or snow or rock avalanches. Melting of ice-cores or frozen ground and piping and seepage are other possible failure mechanisms.

Natural dams may cause upstream flooding as the lake rises and downstream flooding as a result of failure of the dam. Although data are few, for the same potential energy at the dam site, downstream flood peaks from the failure of glacier-ice dams are less than those from landslide, moraine, and constructed earth-fill and rock-fill dam failures. Moraine-dam failures appear to produce some of the largest downstream flood peaks for potential energy at the dam site greater than $10^{11}$ joules. Differences in flood peaks of natural-dam failures appear to be controlled by dam characteristics and failure mechanisms.

\section{INTRODUCTION}

There are many ways in which natural lakes and their dams can form in nature. A general but useful classification of lake basins was proposed by Davis (1882), who categorized lake basins as constructive, destructive, and obstructive. This report is concerned with only one of Davis' classifications, that of obstructive basins. Obstructive barriers include landslide dams, glacier dams, moraine dams, volcanic dams, fluviatile dams, eolian dams, coastal dams; and organic dams (table 1).

This investigation of the hazards associated with natural dams indicates that, despite the great variety of natural dams, only three kinds pose a widespread threat to people and property: landslide dams, glacier dams, and alpine moraine dams.

There are many case studies of individual natural-dam failures, but an integrated view of the phenomenon as a whole does not exist. This paper attempts to use information from a large number of individual case studies to draw comprehensive conclusions about this important natural process. The data base used for this investigation consists of information on approximately 225 natural dams whose formation and (or) failure has been documented in the literature or is know to us from our own field investigations. This data base is believed to be sufficiently large and comprehensive that the conclusions in this report will not radically change even though it is recognized that there are some reported events not known to us and far more events that have never been recorded or reported. 
Table 1.- Types of obstructive dams

[Most dangerous dams are underlined. This table is modified from Hutchinson (1957) and Schuster and Costa (1986a)

\begin{tabular}{|c|c|c|c|}
\hline Type of dam & Example & Type of dam & Example \\
\hline Volcanic dams: & & Fluviatile dams: & \\
\hline Volcanic peaks & $\begin{array}{l}\text { Lake Nicaragua, Nicaragua } \\
\text { (Hutchinson, 1957) }\end{array}$ & Tributary sediments & $\begin{array}{l}\text { Lake Pepin, Minnesota-Wisconsin } \\
\text { (Davis, 1882) }\end{array}$ \\
\hline Lava flows & $\begin{array}{l}\text { Snag Lake, California } \\
\quad \text { (Finch, 1937) }\end{array}$ & $\begin{array}{l}\text { Main channe } 1 \text { sediments } \\
\text { (lateral lakes) }\end{array}$ & $\begin{array}{l}\text { Lake Tung-ting, People's Repub1ic } \\
\text { of China (Hutchinson, 1957) }\end{array}$ \\
\hline Pyroclastic flows & $\begin{array}{l}\text { Rio Magdalena Lake, Mexico } \\
\text { (Silva and others, 1982) }\end{array}$ & Alluvial fans & $\begin{array}{l}\text { Lake Tulare, California } \\
\text { (Hutchinson, 1957) }\end{array}$ \\
\hline Landslide dams: & & Deltas & $\begin{array}{l}\text { Blue Lakes, California } \\
\text { (Davis, 1933) }\end{array}$ \\
\hline Rock and debris avalanches & $\begin{array}{l}\text { Castle Lake, Washington } \\
\text { (Meyer and others, 1986) }\end{array}$ & Levee deposits (oxbow lakes) & $\begin{array}{l}\text { Old River, Louisiana (Campti } \\
\text { Quadrangle USGS } 1: 62,500,1957 \text { ) }\end{array}$ \\
\hline$\underline{\text { Slumps and slides }}$ & $\begin{array}{l}\text { Earthquake Lake, Montana } \\
\text { (Hadley, 1964) }\end{array}$ & Eolian dams: & \\
\hline Mud, debris, and earth flows & $\begin{array}{l}\text { Lake San Cristobal, Colorado } \\
\text { (Crandell and Varnes, 1961) }\end{array}$ & Dunes & $\begin{array}{l}\text { Moses Lake, Washington } \\
\quad \text { (Russell, 1893) }\end{array}$ \\
\hline Liquifaction of sensitive clays & $\begin{array}{l}\text { Yamaska River Lake, Quebec, Canada } \\
\text { (Clark, 1947) }\end{array}$ & Coastal dams: & \\
\hline Peatslides & $\begin{array}{l}\text { Addergoole Bog Lake, Ireland } \\
\quad \text { (Ousley, 1788) }\end{array}$ & Bay-bars & $\begin{array}{l}\text { Freshwater Lagoon, Eureka, } \\
\text { California (Cotton, 1941) }\end{array}$ \\
\hline Scree & $\begin{array}{l}\text { Goatswater, United Kingdom } \\
\quad \text { (Marr, 1916) }\end{array}$ & $\begin{array}{l}\text { Organic dams: } \\
\text { Logs and other vegetation }\end{array}$ & $\begin{array}{l}\text { Lake Okeechobee, Florida } \\
\quad \text { (Hutchinson, 1957) }\end{array}$ \\
\hline $\begin{array}{l}\text { Glacial dams: } \\
\text { Ice }\end{array}$ & $\begin{array}{l}\text { Gapshan Lake (Shyok River) } \\
\text { Pakistan (Mason, 1929) }\end{array}$ & Beaver dams & $\begin{array}{l}\text { Beaver Lake, Montana } \\
\text { (Hutchinson, 1957) }\end{array}$ \\
\hline Moraine & $\begin{array}{l}\text { Nostetuko Lake, British Columbia, } \\
\text { Canada (Blown and Church, 1985) }\end{array}$ & & \\
\hline Ice and snow avalanche & $\begin{array}{l}\text { Rio Plomo, Argentina } \\
\quad \text { (King, 1934) }\end{array}$ & & \\
\hline
\end{tabular}

Natural dams have many economic benefits, including hydropower generation (Anderson, 1948; Adams, 1981) and recreation (Jones and others, 1985), but also can constitute serious hazards. A great deal of information is available about the types and characteristics of constructed dams and the consequences of their failure, but similar information about natural dams is almost nonexistent, despite the fact that natural dams are far more numerous than constructed dams.

Natural dams hold most of the records for size and flood magnitude following failure. The largest flood known to have occurred on the surface of the earth, the "Spokane flood," which carved the channeled scablands in eastern Washington State between 16,000 and 12,000 years ago, was the result of failure of a natural ice dam near Missoula, Montana (Baker, 1973). Another extraordinary documented flood was that caused by the overflow of Pleistocene Lake Bonneville at Red Rock Pass near Preston, Idaho (Malde, 1968), about 14,000 years ago (Scott and others, 1980). The flood was caused by the overtopping and failure of a natural alluvial-fan dam (Gilbert, 1878; Malde, 1968). In 1911 an earthquake in the Soviet Union triggered a rock avalanche (the Usoy landslide) with a volume of 2.0- to 2.5-billion cubic meters, which dammed the Murgab River. This landslide dam is about 550 meters high (Berg, 1950), and the impounded lake (Lake Sarez) overflows the dam (Hutchinson, 1957; Gasiev, 1984). The Usoy landslide dam is nearly three times as high as the world's largest constructed dam, the Nurek rock-fill dam, also in the Soviet Union, which has a height of 300 meters. 
The purposes of this report are to (1) document the methods by which the most dangerous types of natural dams form, (2) determine what constitutes the stability or instability of the dams, (3) compare some of the physical dimensions of the dams and lakes, (4) document the mechanisms by which these natural dams fail, and (5) compare some of the characteristics of the resulting downstream flooding.

\section{LANDSLIDE DAMS}

Landslide dams are remarkably diverse in their formation, characteristics, and longevity. One of the first recorded flooding catastrophes due to a landslide dam occurred in central Java in A.D 1006 (Holmes, 1965, p. 485-487). Many landslide dams have failed catastrophically, causing major downstream flooding and loss of life. At least 2,423 people died in the 1933 flood caused by failure of the large Deixi landslide dam on the Min River in central China (Li and others, 1986). A graphic account of the consequences of the failure of a landslide dam in the Indus River valley, India, is provided by Mason (1929).

\section{Geomorphic Settings of Landslide Dams}

Landslide dams form most frequently where narrow steep valleys are bordered by high rugged mountains. This setting is common in geologically active areas where earthquakes, volcanoes, or glacially oversteepened slopes occur. Geologically active areas usually contain abundant landslide source materials, such as sheared and fractured or hydrothermally altered bedrock, and experience triggering mechanisms to initiate landslides. Steep narrow valleys require relatively small volumes of material to form dams; thus even small mass movements present a potential for forming landslide dams. Such dams are much less common in broad open valleys, but in areas where rivers have incised lacustrine or marine deposits, slides and slumps or quick-clay failures have formed landslide dams (Evans, 1984; Clark, 1947).

\section{Types of Movements that Form Landslide Dams}

Study of 184 cases of landslide dams from the literature and the authors' experience has shown that a broad range of mass-movement types can cause landslide dams (fig. 1 ; table 2). However, most landslide dams are caused by avalanches, slumps and slides, and flows. Relatively few dams have been caused by slope failure in sensitive clays or rock and soil falls. The number of dams resulting from failure of sensitive clays is small because of their limited extent and common occurrence in areas of low relief. The number of dams resulting from falls is small because the volumes of material constituting failures of this type are small.

In general, the highest landslide dams form in steep-walled narrow valleys because there is little area for the landslide mass to spread out. Large-volume earth and rock slumps and slides and rock and debris avalanches are particularly likely to form high dams in narrow valleys because they occur on steep slopes and usually have high velocities that allow complete stream blockage before the material can be sluiced away. 


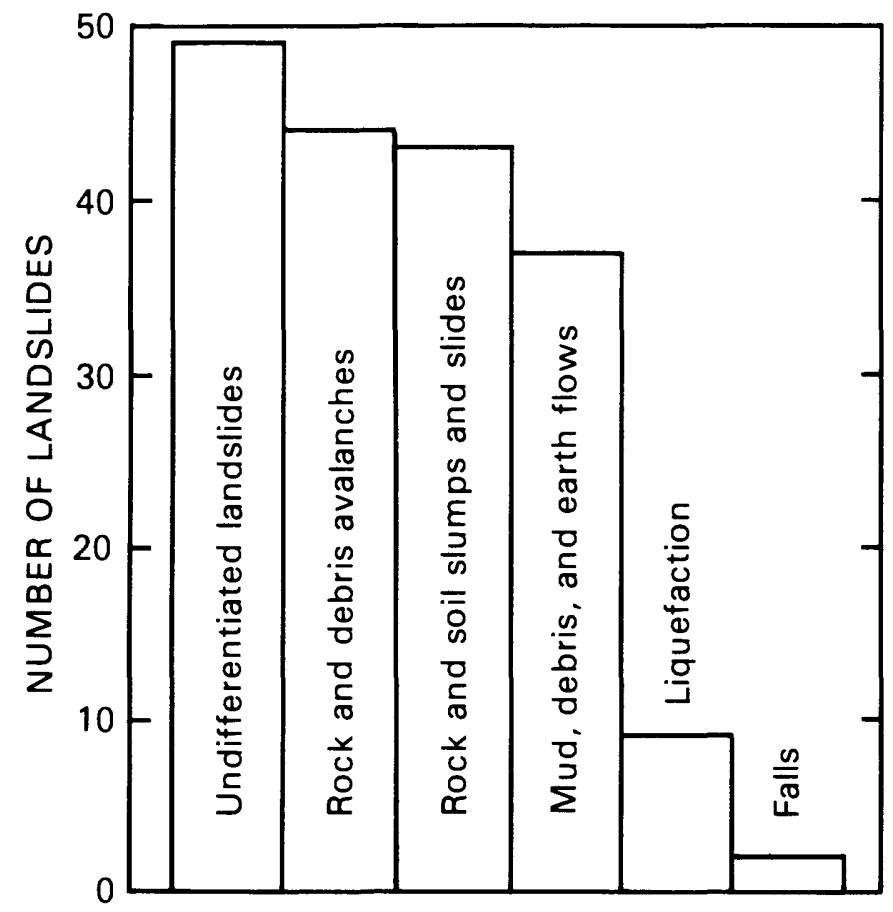

Figure 1.--Graph showing distribution of landslide dams by type of landslide, based on 183 cases from the literature and the authors' experience. Classification based on Varnes (1978)

Commonly, large landslide dams are caused by complex landslides that start as slumps or slides and transform into rock or debris avalanches. An outstanding example was the 2.5-cubic kilometer rockslide/debris avalanche (the world's largest historic landslide) associated with the 1980 major eruption of Mount St. Helens, Washington. This high-velocity landslide originated as a rockslide on the side of the volcano, then transformed into a debris avalanche and traveled 24 kilometers down the North Fork Toutle River valley, impounding or enlarging five large lakes, only three of which remain (Meyer and others, 1986).

If the basal failure zone of a landslide extends beneath the valley floor, upward movement of the streambed itself can alter gradients and form shallow lakes. In this situation, downstream flooding is not great because the lakes are sma11, outlet gradients are low, and the streambed material is not easily erodible.

Mud, debris, and earth flows form a significant percentage of the landslide dams reviewed. Most of these dams have been cause by relatively high-velocity debris flows issuing from tributary valleys to briefly block rivers in main valleys. Generally dams formed in this manner are not high, nor are they particularly resistant to erosion (Li and others, 1986). Thus they commonly overtop soon and breach rapidly. Other kinds of flows are much slower or may form long-lived dams. An example is the 6.5-kilometer slumgullion earthflow that dammed the Lake Fork of the Gunnison River in Colorado about 700 years ago, impounding the 3-kilometer Lake San Cristobal (Crandell and Varnes, 1961). 
Table 2.--We11-documented examples of lands lide dams formed by specific classes of landslides

[Dashes indicate that authors were unable to obtain significant data]

\begin{tabular}{|c|c|c|c|c|c|c|c|c|c|c|c|}
\hline \multirow[b]{2}{*}{$\begin{array}{l}\text { Landslide class } \\
\text { and name }\end{array}$} & \multirow[b]{2}{*}{ Year } & \multirow[b]{2}{*}{$\begin{array}{l}\text { Dammed } \\
\text { river }\end{array}$} & \multirow[b]{2}{*}{$\begin{array}{l}\text { State/ } \\
\text { country }\end{array}$} & \multirow{2}{*}{$\begin{array}{l}\text { Lands lide } \\
\text { volume } \\
\left(\mathrm{m}^{3}\right)\end{array}$} & \multicolumn{3}{|c|}{ Blockage dimensions } & \multicolumn{2}{|c|}{ Lake dimensions } & \multirow[b]{2}{*}{$\begin{array}{l}\text { Dam } \\
\text { failed? }\end{array}$} & \multirow[b]{2}{*}{ References } \\
\hline & & & & & $\begin{array}{l}\text { Height } \\
\text { (m) }\end{array}$ & $\begin{array}{l}\text { Length } \\
\text { (m) }\end{array}$ & $\begin{array}{l}\text { Width } \\
\text { (m) }\end{array}$ & $\begin{array}{l}\text { Length } \\
(\mathrm{km})\end{array}$ & $\begin{array}{l}\text { Volume } \\
\left(m^{3}\right)\end{array}$ & & \\
\hline \multicolumn{12}{|c|}{ Rock and debris avalanches: } \\
\hline Usoy landslide & 1911 & $\begin{array}{l}\text { Murgab } \\
\text { River }\end{array}$ & $\begin{array}{l}\text { Tadzhik- } \\
\text { istan, } \\
\text { U.S.S.R. }\end{array}$ & $2.0-2.5 \times 10^{9}$ & $\begin{array}{c}301 \\
(B 01 t) \\
550 \\
\text { (Gasiev) }\end{array}$ & 1,000 & 1,000 & 53 & -- & $\begin{array}{l}\text { Partial } \\
\text { failure }\end{array}$ & Gasiev, 1984 \\
\hline $\begin{array}{l}\text { Tanggudong debris } \\
\text { slide/avalanche }\end{array}$ & 1967 & $\begin{array}{r}\text { Yalong } \\
\text { River }\end{array}$ & $\begin{array}{l}\text { Sichuan, } \\
\text { People's } \\
\text { Republic } \\
\text { of China }\end{array}$ & $68 \times 10^{6}$ & 175 & 650 & 3,000 & 53 & $680 \times 10^{6}$ & Yes & $\begin{array}{l}\text { Li and others, } \\
1986\end{array}$ \\
\hline $\begin{array}{l}\text { Mayumarca rock } \\
\text { slide/debris } \\
\text { avalanche }\end{array}$ & 1974 & $\begin{array}{l}\text { Mantaro } \\
\text { River }\end{array}$ & Peru & $1.6 \times 10^{9}$ & 170 & 1,000 & 3,800 & 31 & $670 \times 10^{6}$ & Yes & $\begin{array}{l}\text { Hutchinson and } \\
\text { Kojan, 1975; } \\
\text { Lee and } \\
\text { Duncan, } 1975\end{array}$ \\
\hline $\begin{array}{l}\text { Mount St. Helens } \\
\text { rock slide/debris } \\
\text { avalanche }\end{array}$ & 1980 & $\begin{array}{l}\text { North Fork } \\
\text { Toutle } \\
\text { River }\end{array}$ & $\begin{array}{l}\text { State of } \\
\text { Washing- } \\
\text { ton, } \\
\text { U.S.A }\end{array}$ & $2.8 \times 10^{9}$ & av8. $=45$ & $\begin{array}{c}800 \\
\text { (Spirit } \\
\text { Lake) }\end{array}$ & $\begin{array}{l}24 \times 10^{3} \\
\text { (Spirit } \\
\text { Lake) }\end{array}$ & $\begin{array}{c}5.5 \\
\text { (Spirit } \\
\text { Lake) }\end{array}$ & $\begin{array}{l}295 \times 10^{6} \\
\text { (Spirit } \\
\text { Lake) }\end{array}$ & $\begin{array}{l}\text { No } \\
\text { (Spirit } \\
\text { Lake) }\end{array}$ & $\begin{array}{l}\text { Meyer and } \\
\text { others, } 1986\end{array}$ \\
\hline \multicolumn{12}{|c|}{ Rock and soil slumps and slides: } \\
\hline Deixi landslide & 1933 & Min River & $\begin{array}{l}\text { Sichuan, } \\
\text { People's } \\
\text { Republic } \\
\text { of China }\end{array}$ & $150 \times 10^{6}$ & 255 & 400 & 1,300 & 17 & $400 \times 10^{6}$ & Yes & $\begin{array}{l}\text { Chang, 1934; } \\
\text { Li and } \\
\text { others, } 1986\end{array}$ \\
\hline $\begin{array}{l}\text { Lower Gros Ventre } \\
\text { landslide }\end{array}$ & 1925 & $\begin{array}{l}\text { Gros } \\
\text { Ventre } \\
\text { River }\end{array}$ & $\begin{array}{l}\text { Wyoming, } \\
\text { U.S.A. }\end{array}$ & $38 \times 10^{6}$ & 70 & 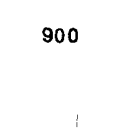 & $\sim 2,400$ & 6.5 & $80 \times 10^{6}$ & Yes & $\begin{array}{l}\text { Emerson, } 1925 ; \\
\text { Alden, } 1928\end{array}$ \\
\hline $\begin{array}{l}\text { Tsao-Ling } \\
\text { rock slide }\end{array}$ & $\begin{array}{c}1941- \\
42\end{array}$ & $\begin{array}{l}\text { Chin-Shui- } \\
\text { Chi River }\end{array}$ & Taiwan & $\begin{array}{l}250 \times 10^{6} \\
\text { (two slides) }\end{array}$ & 217 & 1,300 & 2,000 & -- & $157 \times 10^{6}$ & Yes & Chang, 1984 \\
\hline $\begin{array}{l}\text { Cerro Condor- } \\
\text { Sencca rock slide }\end{array}$ & 1945 & $\begin{array}{l}\text { Mantaro } \\
\text { River }\end{array}$ & Peru & $5.6 \times 10^{6}$ & 100 & 250 & 580 & 21 & $300 \times 10^{6}$ & Yes & Snow, 1964 \\
\hline $\begin{array}{l}\text { Madison Canyon } \\
\text { rock slide }\end{array}$ & 1959 & $\begin{array}{l}\text { Madison } \\
\text { River }\end{array}$ & $\begin{array}{l}\text { Montana, } \\
\text { U.S.A. }\end{array}$ & $21 \times 10^{6}$ & $60-70$ & 500 & 1,600 & 10 & -- & No & $\begin{array}{l}\text { Hadley, } 1964 ; \\
\text { Knight and } \\
\text { Bennett, } 1960\end{array}$ \\
\hline $\begin{array}{l}\text { Thistle earth } \\
\text { slide }\end{array}$ & 1983 & $\begin{array}{l}\text { Spanish } \\
\text { Fork River }\end{array}$ & $\begin{array}{l}\text { Utah, } \\
\text { U.S.A. }\end{array}$ & $22 \times 10^{6}$ & $\sim 60$ & 200 & 600 & 5 & $78 \times 10^{6}$ & No & $\begin{array}{l}\text { Kaliser and } \\
\text { Fleming, } 1986\end{array}$ \\
\hline
\end{tabular}


Table 2. - Well-documented examples of landslide dams formed by specific classes of lands lides--Continued

\begin{tabular}{|c|c|c|c|c|c|c|c|c|c|c|c|}
\hline \multirow[b]{2}{*}{$\begin{array}{l}\text { Landslide class } \\
\text { and name }\end{array}$} & \multirow[b]{2}{*}{ Year } & \multirow[b]{2}{*}{$\begin{array}{l}\text { Dammed } \\
\text { river }\end{array}$} & \multirow[b]{2}{*}{$\begin{array}{l}\text { State/ } \\
\text { country }\end{array}$} & \multirow{2}{*}{$\begin{array}{c}\text { Landslide } \\
\text { volume } \\
\left(\mathrm{m}^{3}\right)\end{array}$} & \multicolumn{3}{|c|}{ Blockage dimensions } & \multicolumn{2}{|c|}{ Lake dimensions } & \multirow[b]{2}{*}{$\begin{array}{l}\text { Dam } \\
\text { failed? }\end{array}$} & \multirow[b]{2}{*}{ References } \\
\hline & & & & & $\begin{array}{l}\text { Height } \\
\text { (m) }\end{array}$ & $\begin{array}{l}\text { Length } \\
\text { (m) }\end{array}$ & $\begin{array}{l}\text { Width } \\
\text { (m) }\end{array}$ & $\begin{array}{l}\text { Length } \\
(\mathrm{km})\end{array}$ & $\begin{array}{c}\text { Volume } \\
\left(\mathrm{m}^{3}\right)\end{array}$ & & \\
\hline \multicolumn{12}{|c|}{ Mud, debris, and earth flows } \\
\hline $\begin{array}{l}\text { Slumgullion earth } \\
\text { flow }\end{array}$ & $\begin{array}{r}1200- \\
1300\end{array}$ & $\begin{array}{l}\text { Lake Fork, } \\
\text { Gunnison } \\
\text { River }\end{array}$ & $\begin{array}{l}\text { Colorado, } \\
\text { U.S.A. }\end{array}$ & $50-100 \times 10^{6}$ & $\begin{array}{c}40 \\
\text { Cestima }\end{array}$ & e) 500 & 1,700 & 3 & -- & No & $\begin{array}{l}\text { Crande11 and } \\
\text { Varnes, } 1961\end{array}$ \\
\hline Gupis debris flow & 1980 & $\begin{array}{l}\text { Ghizar } \\
\text { River }\end{array}$ & Pakistan & -- & 30 & 200 & 300 & 5 & -- & No & $\begin{array}{l}\text { Nash and } \\
\text { others, } 1985\end{array}$ \\
\hline $\begin{array}{l}\text { Polallie Creek } \\
\text { debris flow }\end{array}$ & 1980 & $\begin{array}{l}\text { East Fork, } \\
\text { Hood River }\end{array}$ & $\begin{array}{l}\text { Oregon, } \\
\text { U.S.A. }\end{array}$ & $70-100 \times 10^{3}$ & 11 & -- & 230 & -- & $105 \times 10^{3}$ & Yes & $\begin{array}{l}\text { Gallino and } \\
\text { Pierson, } 1985\end{array}$ \\
\hline \multicolumn{12}{|c|}{ Sensitive-clay failures: } \\
\hline & 1898 & $\begin{array}{l}\text { Riviere } \\
\text { Blance }\end{array}$ & $\begin{array}{l}\text { Quebec, } \\
\text { Canada }\end{array}$ & $2.6 \times 10^{6}$ & 8 & 400 & 3,200 & -- & -- & Yes & Dawson, 1898 \\
\hline & 1945 & $\begin{array}{c}\text { Yamaska } \\
\text { River }\end{array}$ & $\begin{array}{l}\text { Quebec, } \\
\text { Canada }\end{array}$ & $117 \times 10^{3}$ & $3-4$ & 75 & 425 & -- & -- & Yes & Clark, 1947 \\
\hline
\end{tabular}

Two sensitive-clay failures that caused landslide dams to form both occurred in shallow broad valleys in sensitive marine clays (table 2). The dams were low broad blockages that failed by overtopping within a few hours or days.

There are only two known reports of landslide dams formed by rock or earth falls. One was the 1943 "cliff fall" of the bank of the Grande Riviere du Chene in marine clay in Quebec (Clark, 1947); the other was a rock fall that impounded Lake Yashinkul in the central U.S.S.R in 1966 (Pushkarenko, 1982).

\section{Causes of Dam-forming Landslides}

The two most important processes in initiating dam-forming landslides are excessive precipitation (rainfall and snowmelt) and earthquakes (fig. 2). These account for 90 percent of the landslide dams investigated. Volcanic eruptions constitute the third most significant dam-forming process (about 8 percent). Other mechanisms, such as devegetation and stream undercutting and entrenchment, account for the remaining 2 percent. 


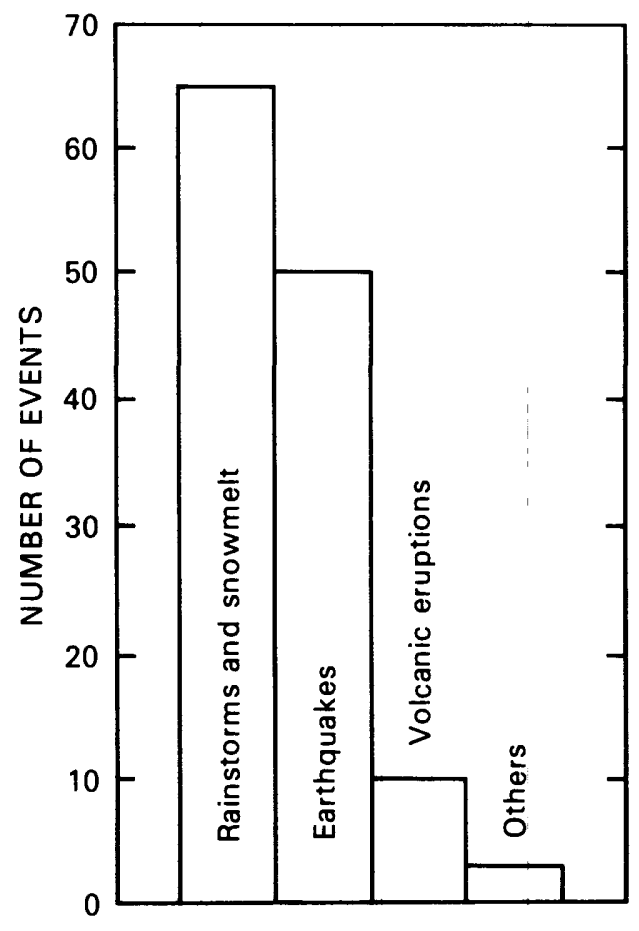

Figure 2.--Graph showing causes of landslides that have formed dams, based on 128 cases from the literature and the authors' experience.

Numerous landslide dams can be formed by a single rainstorm or earthquake. In 1889 in the Totsu River basin, Japan, heavy rainfall produced over 1,100 landslides in the upper 1,100 square kilometers of the watershed. About 250 of these landslides were more than 90 meters wide and 90 meters long and produced 53 landslide dams (Swanson and others, 1986). The 1929 Buller earthquake (magnitude 7.6) in the northwestern part of South Island, New Zealand, produced landslides that formed at least 11 landslide-dammed lakes (Adams, 1981). In 1783, an earthquake in Calabria, Italy, triggered mass movements that formed 215 landslide-dammed lakes (Cotecchia, 1978).

An unusual series of events forming and destroying a landslide dam has been documented for the Tsao-Ling landslide in central Taiwan (Chang, 1984). This case demonstrates just how complex natural-dam processes can be. In 1862, a major earthquake triggered a landslide that dammed the Chin-Shui-Chi River. In 1898 the natural dam failed for unknown reasons. In December 1941 a major earth quake formed another landslide dam 140 meters high at the same location. In August 1942 heavy rainfall caused reactivation of the landslide, and the natural dam increased in height from 140 to 217 meters. In May 1951 several days of intense rainfa11 led to the overtopping and failure of the natural dam. In the subsequent flood 154 people were killed and 564 homes damaged. Dn August 15, 1979, heavy rainfall again activated the landslide, which dammed the river with a natural barrier 90 meters high. Heavy precipitation continued, and 9 days later the landslide dam was overtopped and failed, causing severe downstream flooding. 


\section{Classification of Landslide Dams}

Landslide dams can be classified geomorphically with respect to their relations with the valley floor (Swanson and others, 1986;

fig. 3). Type I dams are small with respect to the width of the valley floor and do not reach from one valley side to the other. Type II dams are larger and span the entire valley floor, occasionally depositing material high up on opposite valley sides. Type III dams fill the valley from side to side and move considerable distances upvalley and downvalley from the failure. These dams typically involve the largest volume of landslide material. Type IV landslide dams form by the contemporaneous failure of material from both sides of a valley. The landslides can adjoin head-to-head in the middle of the valley, or they can juxtapose one another. Type $V$ landslide dams form when the same landslide has multiple lobes of debris that extend across a valley floor and form two or more landslide dams in the same reach of river. Type VI landslide dams involve one or more failure surfaces that extend under the stream or river valley and emerge on the opposite valley side from the landslide. These dams typically involve slow basal sliding and slumping and form lakes by raising the elevation of the streambed, changing the local gradient of the stream.

of the 184 landslide dams classified from around the world, the most common are Types II (44 percent) and III (41 percent). The other types are much more infrequent (Type $I=11$ percent; Type IV $=1$ percent; and Type VI $=3$ percent). Type I landslide-dam lakes commonly are small, low, and usually not hazardous. Type II landslide-dam lakes are larger and much more dangerous. Type III dams not only can form large hazardous lakes behind the obstruction, but also can block tributaries to the main valley, creating additional potentially dangerous lakes. This is the case at Mount St. Helens, Washington, as a result of the 1980 debris avalanche that dammed tributaries to the North Fork Toutle River. Type IV and V landslide-dam lakes can be hazardous if the valleys are narrow and the volumes of landslide materials are large enough to form high dams. Only one example of a type IV landslide dam is known, the Yinping landslide blockage of the Min River, Sichuan Province, China, which forms Da Lake (Li and others, 1986; fig. 4). Only one example of a Type V landslide dam is known, the Slide Lake rockfall-avalanche in Glacier National Park, Montana (Butler and others, 1986). Only a few examples of Type VI are known, from Japan (Swanson and others, 1986) and one from Colorado (Muddy Creek landslide). This type of landslide dam typically poses less threat of downstream flooding than the other types because there may never be a complete blockage. The stream may continue to flow over the dam debris, so that the likelihood of abrupt overtopping and rapid incision of the dam is unlikely. Water storage usually is small and the stream gradient not relatively steep. 

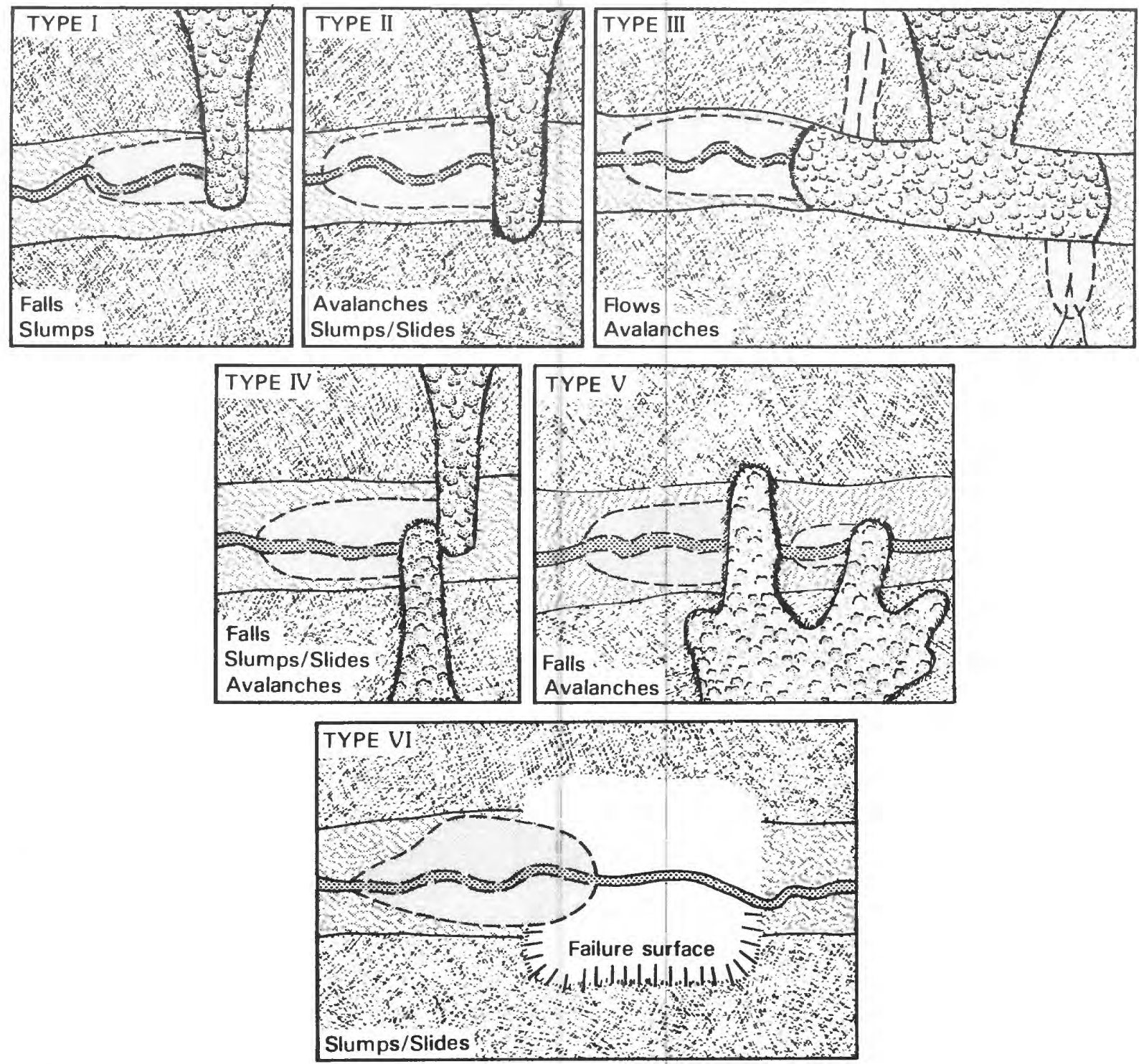

Figure 3.--Diagrams showing classification of landslide dams. Mass-movement processes most likely to form particular landslide dams are listed in lower left corner of each category. (Modified from Swanson and others, 1986) 


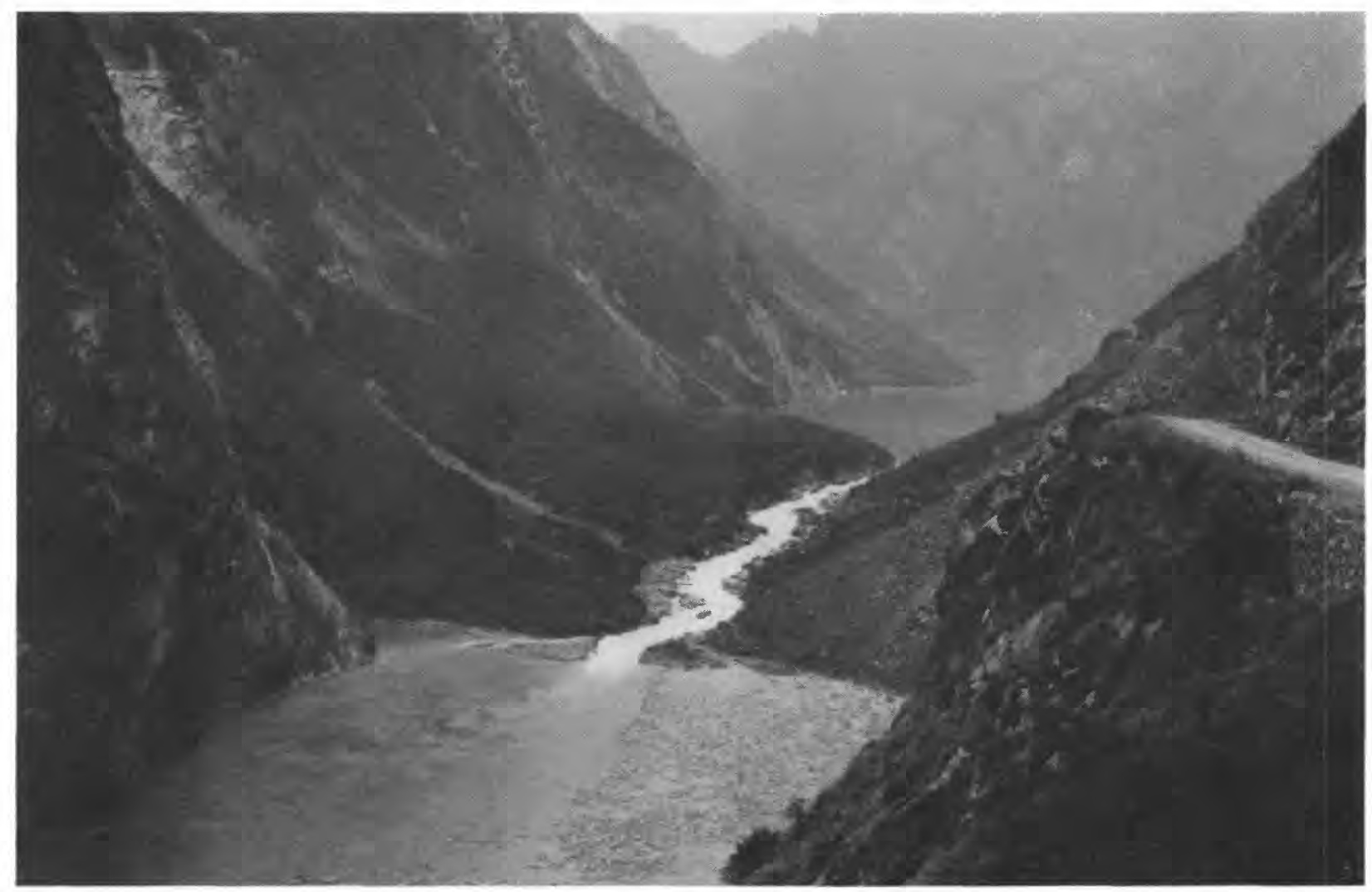

Figure 4.--Photograph view upstream along the Min River, Sichuan Province, Peoples Republic of China, showing remains of the 1933 earthquake-induced Yinping landslide dam. Xico Lake (foreground) was impounded by another landslide dam caused by the same earthquake.

\section{Modes of Failure of Landslide Dams}

A landslide dam in its natural state differs from a constructed embankment dam in that it is made up of a heterogeneous mass of poorly consolidated earth material and has no channelized spillway or other protected outlet. Because of the lack of a protected spillway, landslide dams commonly fail by overtopping, followed by breaching from erosion by the overflowing stream (fig. 5). In most documented cases, the breach has resulted from the fluvial erosion of the landslide material by headcutting originating at the toe of the dam and progressively moving upstream to the lake. When the headcut reaches the lake, breaching occurs (Lee and Duncan, 1975). The breach commonly does not erode down to the original river level. In this situation, smaller lakes can remain after dam failure. In some situations the landslide dam will not fail during first filling and overtopping. Subsequent failure can occur by surface erosion accompanying unusually large runoff periods. This was the case in the failure of the landslide dams at Gros Ventre, Wyoming, and Lake Elizabeth, Australia.

Because landslide dams have not undergone systematic compaction, they may be porous, and seepage through the dams potentially could lead to failure by internal erosion (piping). Seeps have been noted on the downstream faces of many landslide dams. Examples are the 1925 Lower Gros Ventre landslide in northwestern Wyoming, which failed in 1927 from overtopping (Alden, 1928), and the 1945 Cerro Condor-Sencca landslide dam in Peru, which failed in 1945, probably because of "violent" seepage and piping (Snow, 1964). 
However, only two cases where a landslide dam actually has failed in this manner are known: the 1945 Cerro Condor-Sencca landslide dam and the 1966 breach of the landslide dam that impounded Lake Yaskinkul on the Isfayramsay River in the south-central U.S.S.R (Glazyrin and Reyzvikh, 1968). In these failures, piping and undermining caused collapse of the dam, followed by overtopping and breaching.

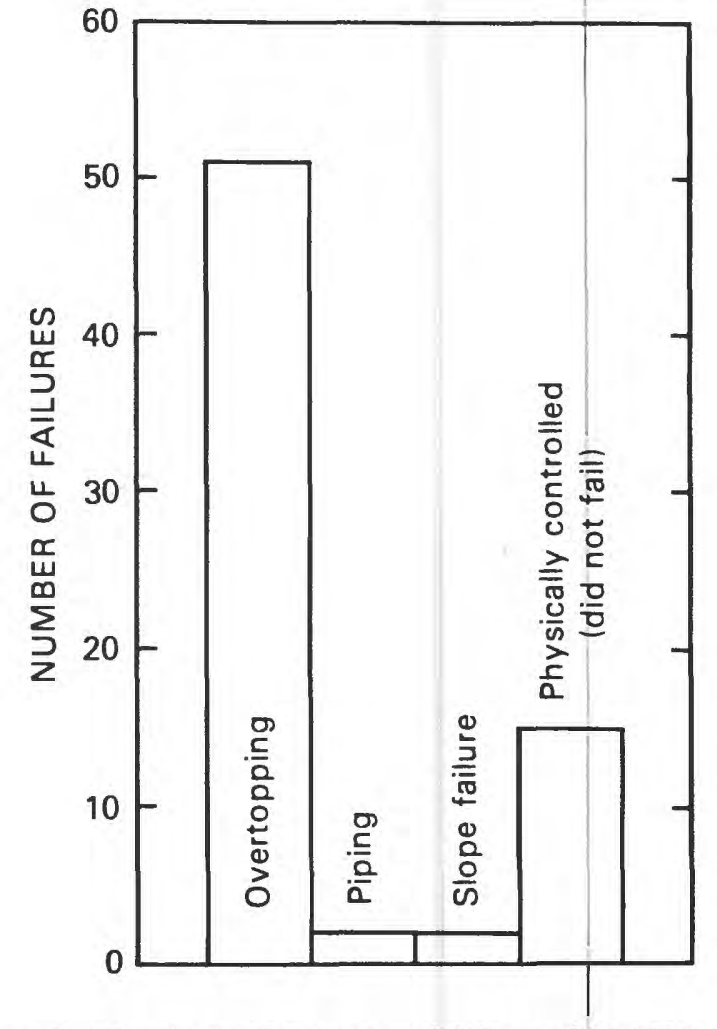

Figure 5.--Graph showing modes of failure of landslide dams, based on 55 failures from the literature and the authors' experience.

A landslide dam with steep upstream or downstream faces is susceptible to slope failure. If the dam has a narrow cross section or if the slope failure is progressive, the crest may fail, leading to overtopping and breaching. However, nearly all upstream and downstream faces of landslide dams are at the angle of repose of the material or shallower, and the dams are much wider than tall. In such cases, slope failures are rare. A special type of slope failure involves lateral erosion of the dam by a stream or river (for example, Jackson Lake, Mount St. Helens, Washington, U.S. Geological Survey, Vancouver, Washington, unpublished data, 1985; Hole-in-the-Wall Gulch, Oregon, J . M. Geist, U.S. Forest Service, ora1 commun., 1986). One we11-documented example exists in which failure of the downstream slope of a landslide dam may have contributed to overall failure: the 1945 Cerro CondorSencca blockage of the Mantaro River, Peru (Snow, 1964). 


\section{Longevity of Landslide Dams}

Landslide-dammed lakes may last for several minutes or several thousand years, depending on many factors, including volume, texture, and sorting of the blockage material; rates of seepage through the blockage; and rates of sediment and water flow into the newly formed lake. Rapid assessment of the upstream and downstream flood potential after formation of a landslide dam is essential. Seventy-three examples of landslide-dam failures in which the time to failure is known are compiled in figure 6 and indicate how dangerous landslide dams can be. Twenty-seven percent of the dams failed within 1 day of formation; 41 percent failed within 1 week; about 50 percent failed within 10 days; 80 percent failed within 6 months, and 85 percent failed within 1 year of formation. It is important to note, however, that these percentages pertain only to landslide dams that have failed. Numerous other landslide dams have formed and not failed.

The three factors that seem to be most relevant to the longevity of a landslide dam are (1) volume and rate of inflow to the impoundment, (2) size and shape of the dam, and (3) geotechnical characteristics of the dam. In many cases the amount of flow in a stream and thus the rate at which a natural lake will fill is directly proportional to the size of the upstream drainage area. The duration of a landslide dam is apt to be short whenever a small landslide blocks a stream with a large drainage area (Swanson and others, 1985). Unless seepage through the dam equals the inflow, the dam can fill to overtopping. Rapid inflow behind a low, small landslide dam means that the new natural lake probably will fill quickly to overflowing, which may lead to failure of the landslide dam.

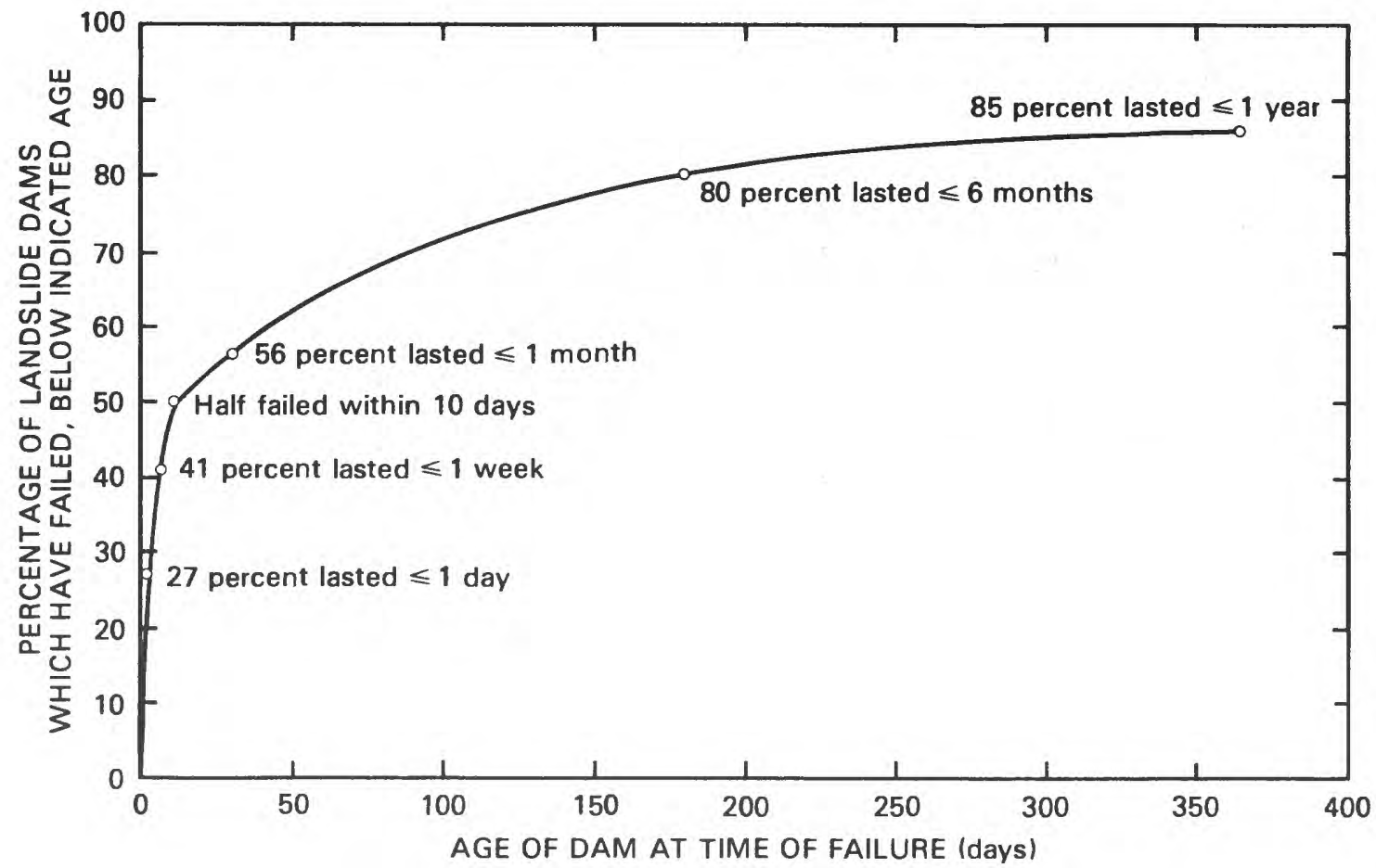

Figure 6.--Graph showing length of time before failure of landslide dams, based on 73 cases from the literature and the authors' experience. 
Landslide dams of a predominantly soft, low-density, fine-grained, or easily liquified sediment are hazardous. Landslide dams composed of these materials can be expected to have relatively low bulk densities and resistances to erosion. Failure following overtopping is common. Peak discharge from the overtopping failure of a landslide dam is dependent on cohesive strength and friction angle of the landslide material (Fread, 1985). If the dam materials are mostly saturated, shear strength may be low and the dam may not be able to withstand the increasing hydrostatic pressure resulting from the impoundment, or the dam may erode rapidly when overtopped.

Some landslide dams are more resistant to all types of failure mechanisms than others. The most important characteristic in preventing failure is resistance to erosion, either at the surface of the dam from surface-water runoff or inside the dam from piping and seepage. As might be expected, landslide dams consistinglof large or cohesive particles resist failure better than dams containing large percentages of soil or soft rock. Landslide dams typically are much wider than constructed earth-fill and rock-fill dams and involve larger volumes of material. The shear bulk of many such blockages provides some degree of protection against failure by any mechanism.

Sorting of landslide sediment also is an important factor. Natural materials with D15/D85 ratio greater than 5 are susceptible to internal erosion by piping (Sherard, 1979). If the material forming the landslide dam is permeable, easily eroded sediment, such as sand with a small proportion of silt and clay, rising water levels behind the dam may force water through the permeable beds and lead to piping and erosion that could cause the dam to fail.

Slope stability of the upstream and downstream faces of a dam is inversely related to the steepness of these faces. Obviously, landslide dams with relatively gentle surface slopes are less susceptible to slope failure than those with steep slopes.

In some cases lakes have not overtopped their dams because lake inflow is less than losses due to seepage, evaporation, or withdrawals for irrigation. An example is Bitang Lake in Gansu Province, China, which has stabilized at a level considerably below the crest of the landslide dam that impounded it in 1961 ( $\mathrm{LI}$ and others, 1986).

In a few cases landslide-dammed lakes have formed natural spillways across adjacent bedrock abutments which prevent overtopping and possible breaching of the dams. This occurs when the surface of the toe of the landslide dam is higher than the surface of the adjacent bedrock abutment. A we11-known example of a natural bedrock spillway for a landslide-dammed lake is the outlet across the left abutment of the Slumgullion earthflow in southwestern Colorado (Schuster, 1985). This natural spillway has existed for 700 years.

\section{Physical Measures to Improve the Stability of Landslide Dams}

Construction of control measures (most commonly spillways) has been attempted in recent years on many major landslide dams as soon as possible after formation. However in some cases overtopping has occurred before satisfactory control measures could be constructed. This happening is particularly common in outlying areas of mountainous topography where transporting heavy construction equipment to the site is difficult. 
The most simple and most common method for stabilizing landslide dams has been construction of channelized spillways, either across adjacent bedrock abutments or directly over the landslide dams. A wellknown example of a successful spillway across a landslide dam is the spillway constructed in 1959 by the U.S. Army Corps of Engineers on the Madison Canyon landslide, Montana (Harrison, 1974; fig. 7).

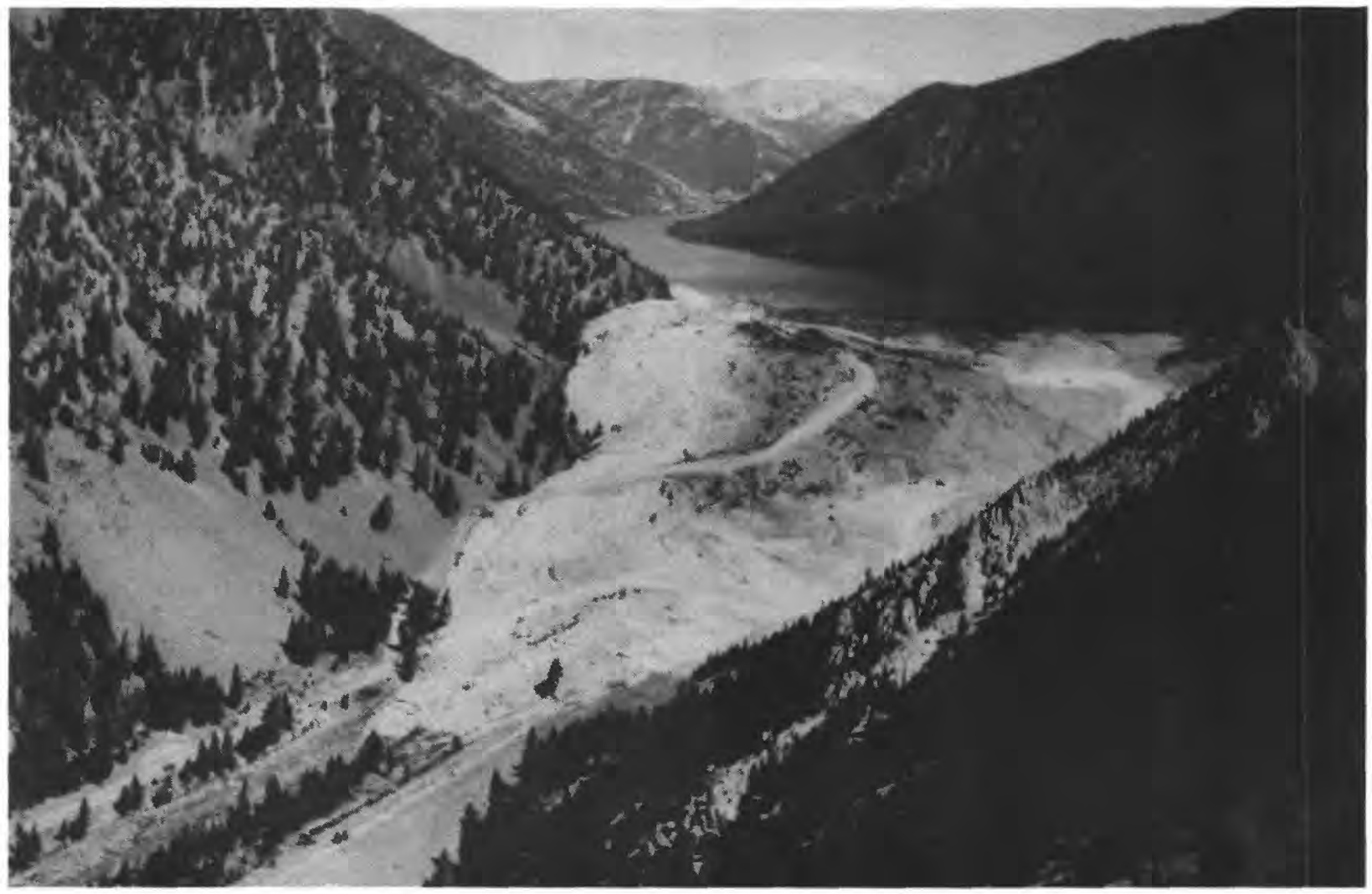

Figure 7.--Photograph of the landslide dam formed by the 1959 Madison Canyon landslide, Montana, and Earthquake Lake, which it impounds. (Photograph by J. R. Stacy, U.S. Geological Survey)

Spillways excavated across landslide dams are not always successful in preventing dam failure and subsequent flooding because they sometimes are eroded rapidly by outflow waters. Such was the case in the 1976 landslide damming of the Rio Quemaya in Guatemala, where highway workers trenched the landslide dam to drain the lake. It drained too rapidly and caused a flood that swept away several people (Harp and others, 1981).

In a few cases, large-scale blasting has been used to excavate new river channels through landslide dams. This technique was used in 1981 to open a channel through the Zhouqu landslide dam on the Bailong River in Gansu Province, China. Other methods of stabilizing lake levels behind landslide dams and preventing overtopping include pipe and tunnel outlets and diversions. Both a pipe and a tunnel have been used to control discharge from Spirit Lake, Mount St. Helens, Washington (Sager and Chambers, 1986), and at Thistle, Utah (Kaliser and Fleming, 1986). 


\section{GLACIER DAMS}

Glacier dams are dams that impound water in, on, beneath, or behind masses of glacial ice: These dams can occur in any area covered by continental or valley glaciers. Other related natural dams not discussed include icefalls (Ballantyne and McCann, 1980), snow and ice avalanches (King, 1934), and snowbanks (Church, 1972).

Jokulhlaup ("glacier burst") is the Icelandic term for a flood caused by the sudden and usually catastrophic release of water impounded within or behind glacier ice (Thorarinsson, 1953). Some of the largest floods known to have occurred in the history of the Earth were the result of the failure of ice dams during the waning stages of the Pleistocene. The failure of ice dams has caused great loss of 1 ife and property damage in many places (table 3 ), including Iceland (Thorarinsson, 1939, 1953, 1957); northern India (Hewitt, 1982); Pakistan (Nash and others, 1985); Peru (Lliboutry and others, 1977); Norway (Aitkenhead, 1960); Alaska (Post and Mayo, 1971); Washington and Oregon (Richardson, 1968); Switzerland, Austria, France, and Italy (Eisbacher and Clague, 1984); and Canada (Clarke, 1982; Young, 1980).

\section{Geomorphic Settings of Ice Dams}

Ice dams can form in any area covered by or adjacent to continental or alpine glaciers (fig. 8). Glacial ice may obstruct drainage and form lakes in numerous ways (table 4 ; fig. 9).

One of the most hazardous kinds of ice-dammed lakes is category $G$ in table 4, lakes formed in main valleys dammed by tributary-valley glaciers. These lakes can be large, and the ice dam can be relatively small. These dams usually form as a result of glacial surges, in which the velocity of a tributary glacier temporarily can increase 10- to 100 fold (Meier and Post, 1969). In the upper Indus River valley of Pakistan at least 18 tributary glaciers have dammed major valleys (Hewitt, 1982). The Chong Khumdan glacier op the Shyok River, a large tributary of the Indus River, is a classic example of a glacier projecting into and blocking a major valley. Numerous disastrous floods have occurred from the temporary blocking and failure of the ice dams in the valley of the Shyok River; the most notable was the flood of 1929 (Mason, 1929; Gunn, 1930).

\section{Modes of Failure of Ice Dams}

Ice-dam failures are complicated phenomena, involving many sets of independent factors. Glacier dams often fail periodically, with return periods of 1 to 10 years. About 95 percent of the more than 50 jokulhlaups in the Alps occurred from June through September, with maxima in June and August (Tufue11, 1984). The failure of glacier dams can occur by erosion of a drainage channel under, through, or over the ice dam. Many ice dams fail by rapid drainage through englacial or subglacial tunnels (Gilbert, 1971). Such tunnels can be tens of kilometers long (Nye, 1976), and the outlet location can change by hundreds of kilometers from one failure to another (Sturm and Benson, 1985). The ice comprising these dams behaves plastically, deforming and flowing to reestablish a blockage of drainage by closing englacial or subglacial tunnels or by squeezing breaches shut. The lake then can reform by collecting runoff from the drainage area upstream, from surface runoff from the glacier, and from subglacial flow into the reservoir. 
Table 3.--Well-documented examples of glacial-ice dems that have failed, producing jokulhlaups

\begin{tabular}{|c|c|c|c|c|c|c|}
\hline Lake name & Location & $\begin{array}{l}\text { Year } \\
\text { failed }\end{array}$ & $\begin{array}{c}\text { Dam } \\
\text { height } \\
(m)\end{array}$ & $\begin{array}{c}\text { Lake } \\
\text { volume } \\
\left(m^{3}\right)\end{array}$ & $\begin{array}{c}\text { Flood } \\
\text { peak } \\
3 / \mathrm{m} / \mathrm{s})\end{array}$ & Reference \\
\hline Missoula & $\begin{array}{l}\text { Montana, } \\
\text { U.S.A. }\end{array}$ & $\begin{array}{l}16,000- \\
12,000 \\
\text { yrs. B.P. }\end{array}$ & 1,078 & $2,184,000 \times 10^{6}$ & $21.3 \times 10^{6}$ & $\begin{array}{c}\text { Baker, 1973; Clarke } \\
\text { and others, } 1984\end{array}$ \\
\hline Vatnsdalur & Iceland & 1898 & 372 & $120 \times 10^{6}$ & 3,000 & Thorarinsson, 1939 \\
\hline $\begin{array}{l}\text { Chong Kumdan } \\
\text { (Shyok River) }\end{array}$ & India & 1929 & 120 & $1,350 \times 10^{6}$ & 22,650 & $\begin{array}{l}\text { Gunn, 1930; Hewitt, } \\
1982\end{array}$ \\
\hline Demmevatn & Norway & 1937 & 406 & $11.6 \times 10^{6}$ & 1,000 & $\begin{array}{l}\text { Clague and Mathews, } \\
1973\end{array}$ \\
\hline Graenalon & Iceland & 1939 & 535 & $1,500 \times 10^{6}$ & 5,000 & Thorarinsson, 1939 \\
\hline Gorner & Switzerland & 1944 & $?$ & $>6 \times 10^{6}$ & 200 & Haeber11, 1983 \\
\hline Gjanupsvatn & Iceland & 1951 & 167 & $20 \times 10^{6}$ & 370 & Arnborg, 1955 \\
\hline Lake George & $\begin{array}{l}\text { Alaska, } \\
\text { U.S.A. }\end{array}$ & 1958 & 40 & $1,730 \times 10^{6}$ & 10,100 & Stone, 1963 \\
\hline Tulsequah & $\begin{array}{l}\text { British } \\
\text { Columbia, } \\
\text { Canada }\end{array}$ & 1958 & 210 & $229 \times 10^{6}$ & 1,556 & Marcus, 1960 \\
\hline Summit & $\begin{array}{l}\text { British } \\
\text { Columbia, } \\
\text { Canada }\end{array}$ & 1965 & 620 & $251 \times 10^{6}$ & 3,260 & Mathews, 1965 \\
\hline $\begin{array}{l}\text { Ekalugad } \\
\text { Valloy }\end{array}$ & $\begin{array}{l}\text { Baffin } \\
\text { Island, } \\
\text { Canada }\end{array}$ & 1967 & 120 & $4.8 \times 10^{6}$ & 200 & Church, 1972 \\
\hline Strupvatnet & Norway & 1969 & 186 & $2.6 \times 10^{6}$ & 150 & Whalley, 1971 \\
\hline Hazard Lake & $\begin{array}{l}\text { Yukon, } \\
\text { Canada }\end{array}$ & 1978 & 300 & $19.6 \times 10^{6}$ & 640 & Clarke, 1982 \\
\hline
\end{tabular}




\begin{tabular}{|c|c|}
\hline \multicolumn{2}{|c|}{$\begin{array}{l}\text { Table 4.-- Classification of ice-dammed lakes } \\
\text { (from Blachut and Ballantyne, 1976) }\end{array}$} \\
\hline Type of Lake & Example \\
\hline A. Supraglacial & Generally small and not hazardous \\
\hline B. Marginal-ponded & $\begin{array}{l}\text { Unnamed lake, Greenland (Sugden } \\
\text { and others, 1985) }\end{array}$ \\
\hline C. Converging ice-stream-ponded & $\begin{array}{l}\text { Between Lake, Axel Heiberg Island, } \\
\text { Canada (Maag, 1969) }\end{array}$ \\
\hline D. Tributary stream valley-ponded & $\begin{array}{l}\text { Flood Lake, British Columbia, } \\
\text { Canada (Clarke and Waldron, 1984) }\end{array}$ \\
\hline E. Tributary glacier valley-ponded & $\begin{array}{l}\text { Lago Rico, Argentina (Nichols and } \\
\text { Miller, } 1952\end{array}$ \\
\hline F. Interglacial-ponded & $\begin{array}{l}\text { Tulsequah Lake, British Columbia, } \\
\text { Canada (Marcus, 1960) }\end{array}$ \\
\hline G. Dammed by tributary glacier & $\begin{array}{l}\text { Shyok River Lake, Upper Indus } \\
\text { Valley, Pakistan (Gunn, 1930; } \\
\text { Mason, 1929) }\end{array}$ \\
\hline H. Proglacial ice-dammed & $\begin{array}{l}\text { Generally small with valley glacier, } \\
\text { can be gigantic with contenental } \\
\text { ice sheets (e.g., Glacial Lake } \\
\text { Agassiz) }\end{array}$ \\
\hline $\begin{array}{l}\text { I. Miscellaneous } \\
\text { (ice-dammed craters on volcanoes) } \\
\text { (large englacial or subglacial } \\
\text { water bodies) }\end{array}$ & $\begin{array}{l}\text { Grimsvotn, Iceland } \\
\text { (Thorarinsson, 1953) }\end{array}$ \\
\hline
\end{tabular}

Another commonly-evoked failure mechanism is the hydrostatic flotation hypothesis of Thorarinsson (1953), whereby subglacial drainage becomes possible when hydrostatic pressure of water in an ice-dammed lake exceeds the ice-overburden pressure in an ice dam. This excess occurs when the depth of water behind an ice dam reaches 0.9 times the height of the ice dam. The story is not so simple as measuring the lake level behind an ice dam, because some ice-dammed lakes fail before filling to 0.9 times the ice-dam height, and most lakes continue to drain well after water levels decline below this critical level. Lifting of the ice dam only may be a triggering mechanism of failure, followed by other processes that allow continued drainage of the lake, such as erosion of drainage-ways under the ice by escaping lakewater, uneven settling of the ice dam after flotation, or formation of tension crevasses from flotation (Marcus, 1960).

Other mechanisms for failure of glacier dams include (1) slow plastic yielding of ice from hydrostatic-pressure differences between the lake and adjacent less-dense ice, (2) crack progression under combined shear stress from glacier flow and hydrostatic pressure, (3) water overflow erosion of a breach in the dam, (4) subglacial melting by volcanic heat, and (5) weakening of the ice dam by earthquakes (Post and Mayo, 1971). 


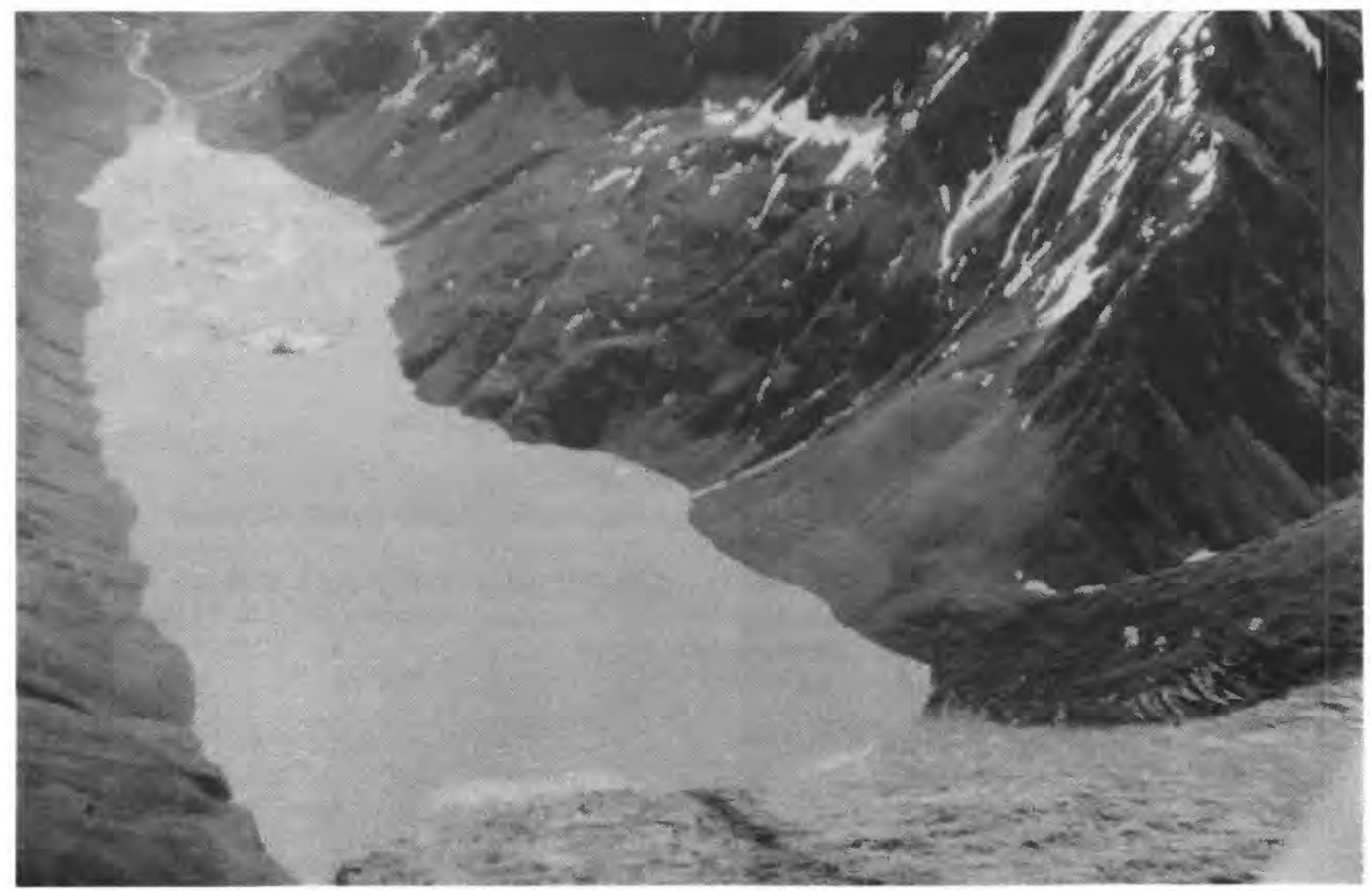

Figure 8.--Photograph of a glacier-dammed lake in a tributary valley (type D, table 4), Coast Mountains, Alaska. Note the strand lines indicating previously higher lake levels. (Photograph by W. C. Bradley, University of Colorado)

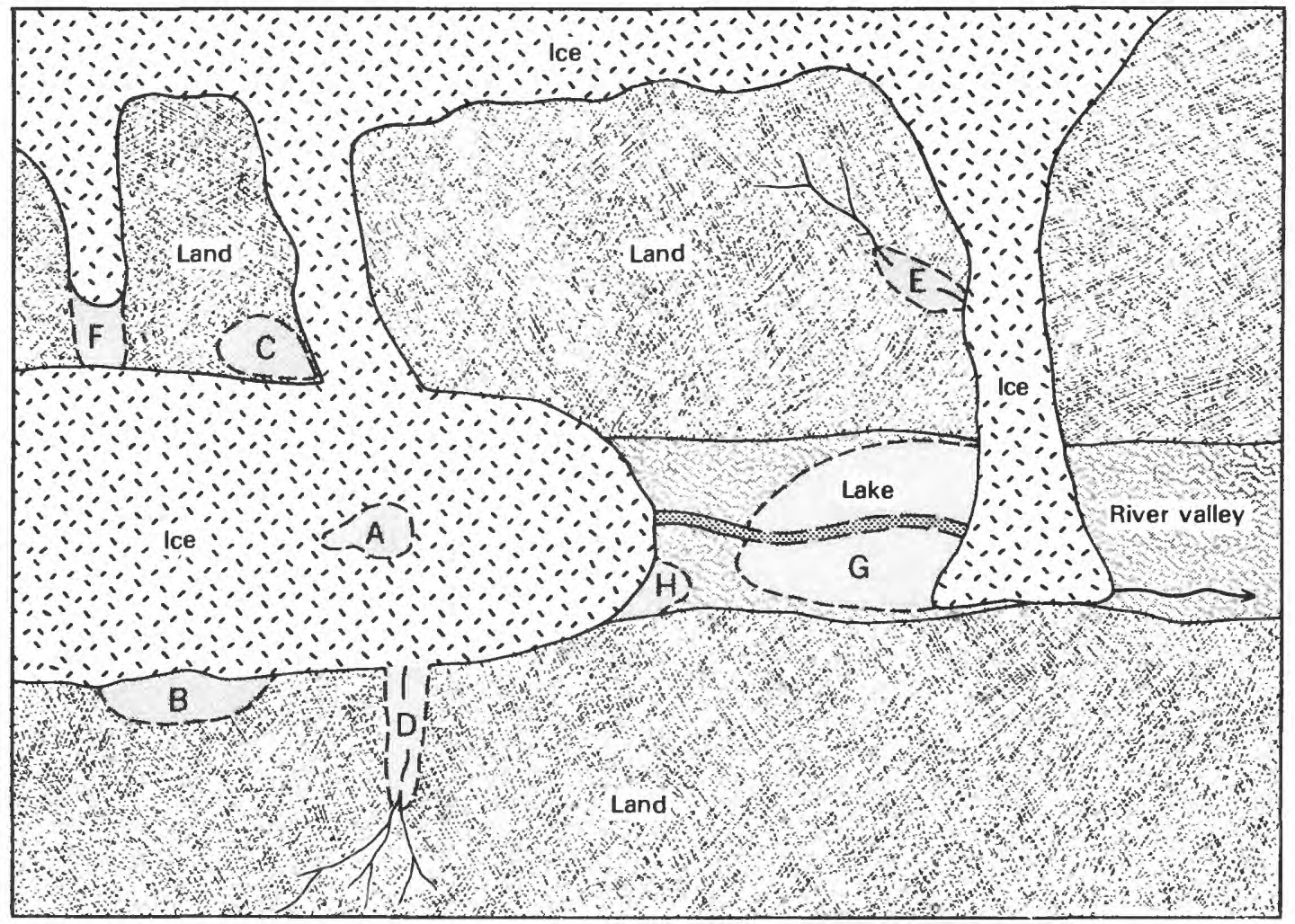

Figure 9.--Diagram showing classification of glacial-ice dams, keyed to table 4. (Modified from Maag, 1969; and Blackut and Ballantyne, 1976) 
The type of ice forming an ice dam (cold polar and subpolar ice versus warmer temperate ice) affects the potential failure mechanisms. Glacier dams formed of cold polar and subpolar ice are relatively tight and dense, have temperatures below the pressure melting point, are dry at their bases, and generally drain supraglacially or marginally by downmelting of an outlet channel (Marcus, 1960; Maag, 1969). Warmer temperate glacier dams are more fractured and less dense, have subglacial-meltwater flow, and tend to fail by sudden englacial or subglacial breaching and drainage (Blachut and Ballantyne, 1976).

\section{Longevity and Controls of Glacler Dams}

Some glacier dams fail by means of non-catastrophic seasonal drainage outlets; the ice dams at Base Camp Lake, Greenland (Clement, 1984), are an example. Others fail catastrophically on an annual or near-annual basis. An example is the glacier dam that impounded Lake George, Alaska. This dam failed annually from at least 1918 until 1966 (Bradley and others, 1972). Some glacier dams fail several times during 1 year; others fail irregularly. Irregular damming and failure are believed related to local-climate control of glacier activity, filling rates, and lake temperatures. In some situations, the overflow outlet for a glacier-dammed lake is controlled by overflow across low bedrock cols around the perimeter of the lake (Sugden and others, 1985).

Numerous case studies of glacier-dammed lakes indicate that the frequency of glacier-dam failure is likely to change with time. Thorarinsson (1939) demonstrated that, as a glacier recedes and melts, failures increase in frequency but decrease in magnitude, eventually ending with establishment of a permanent outlet. This pattern of response to glacial recession, increasing ice-dam failure, and decreasing flood magnitudes has been documented for Tulsequah Lake, British Columbia (Marcus, 1960).

Some factors appear to predicate the failure of a glacier dam. Filling to some characteristic level is one example. A unique lake level may signal the beginning of hydrostatic flotation or overtopping of the ice barrier. A glacier dam with a cyclical history of failure may continue to fail, provided no change occurs in the size or shape of the ice dam. At Strandline Lake, Alaska, precursor indications of a glacier-dam failure include (1) rapid iceberg calving from the glacier, producing numerous icebergs; (2) filling of a number of small supraglacial pools; and (3) lake-level rise to a pre-identified failure level (Sturm and Benson, 1985).

Artificial controls of the levels of glacier-dammed lakes have been attempted in several locations. In the Alps, trenching across a glacier dam or tunneling through rock or ice has allowed control of dangerous lakes (Eisbacher and Clague, 1984). This is not always successful (Mathews, 1965). In Argentina, 500-kilogram bombs were dropped on a glacier dam in an unsuccessful attempt to destroy the dam (Nichols and Miller, 1952). 
Many moraine dams occur throughout the world, but the most dangerous of these are restricted to alpine regions affected by the advances and retreats of valley glaciers in the last several centuries in steep mountain areas. Some excellent case studies have been made of moraine-dam failures in Peru (Lliboutry and others, 1977) and in British Columbia (Blown and Church, 1985), but relatively little is known about these natural dams compared to landslide or glacier dams. Moraine-dam failures have been reported from Napal (Galay, 1985; Vuichard and Zimmermann, 1987), India and Pakistan (Burgisser and others, 1982), the U.S.S.R. (Yesenov and Degovets, 1979), Oregon (Nolf, 1966; Laenen and others, 1987), Peru (Lliboutry and others, 1977), Canada (Clague and others, 1985), Austria (Eisbacher and Clague, 1984), and Argentina (Rabassa and others, 1979).

\section{Geomorphic Settings of Moraine Dams}

A globally synchronous readvance of glaciers during the last few centuries has been documented (Grove, 1979) and referred to as the Little Ice Age (Matthes, 1939) or late-neoglacial time (Porter and Denton, 1967). Neoglacial time ended in the late 19th Century, and since then many mountain glaciers have retreated significantly (Porter and Denton, 1967), leaving behind many moraine-dammed lakes.

These late-neoglacial and contemporary moraine-dammed lakes are hazards because (1) they are young and located at such high elevations that vegetation has not completely stabilized their slopes, (2) slopes are steep (some greater than 40 degrees), (3) thermal degradation melting an ice or snow core could render them unstable, and (4) they may be located close to an ice front and steep, rock-walled cirques and valleys. Anomalous meltwater inflow or ice and rock falls into the lakes may precipitate breaching and failure of these dams.

A variety of types of moraines may form in alpine areas. Push moraines originate when glacier ice advances and bulldozes sediment into a ridge, typically less than 9 meters high (Sugden and John, 1976). A typical push moraine has a shallow upstream dipping surface overridden by the glacier and a steeper downstream face formed by material cascading down the glacier surface. Because at least part of the moraine dam has been overridden by the glacier, some of the dam is partially compacted; this compaction adds an increment of stability that does not exist in other kinds of moraine dams. Push moraines are not common dams, or they only contain small lakes.

Ice-thrust moraines originate from the collection of sediment and debris erodes from the base of a glacier and thrust along shear planes to the front margin of the ice. Moraines can form to heights of 100 meters or more if the glacier is on a steep gradient, flows rapidly, and actively erodes material from its boundary. Ice-thrust moraine sediments are relatively compact and contain more fines than other types of moraine dams.

Dump moraines originate from the dumping down the ice front of sediment and debris from within the ice and on the ice surface. The form and size of dump moraines are controlled by rate of ice movement, rate of surface ablation, volume of sediment in and on the ice, and meltwater effects. A dump-moraine dam will be heterogeneous mixture because material moving from the ice to the moraine comes from diverse sources, lithologies, textures, and transport mechanisms. 
Dump moraines typically have steep ice-contact upstream slopes where the moraine was buttressed by the glacier and flatter distal downstream-

facing slopes (Andrews, 1975). For large dump moraines to form, forward motion of the glacier must balance the melting rate. Till in dump moraines tends to be relatively loose, uncompacted, and free of fines. Steep slopes, and uncompacted and noncohesive sediment make dump-moraine dams the least stable.

Ice-cored moraines can originate when sediment at the base of a glacier is moved upward toward the ice surface by compression and thrusting. Ice-cored moraines can be as much as 90 percent ice by volume, with only thin till covers. The ice core can originate as glacial ice or snow (Ostrem, 1964). Ice cores in high-altitude or subpolar continental climates can last for 1,000 years (Andrews, 1975). Naturally, the melting of an ice-cored moraine impounding a lake can lead to the collapse and failure of the moraine dam. The presence of an ice-core in a moraine may be indicated by moist areas or seeps in moraine-dam walls above lake levels late in the summer or early autumn before sub-freezing temperatures occur.

\section{Modes of Failure of Moraine Dams}

Comprehensive descriptions of the failure of moraine dams are rare (table 5). The Cordillera Blanca and Cordillera Huayhuash of northcentral Peru are regions that have an especially large number of moraines enclosing narrow, steep valleys. Nearly all glaciers of the Cordillera Blanca lie behind large moraines of late-neoglacial age and contain lakes (Lliboutry and others, 1977). In 1941, Laguna Cohup, a proglacial moraine-dammed lake, drained rapidly when the moraine dam failed. The resulting flood of mud and water (known in Spanish as "alluvion") destroyed almost half the town of Juaraz and killed about 6,000 people (Ericksen and others, 1970; Eisbacher, 1982). This disaster led to a major effort toward control and lowering of lake levels in dangerous moraine-dammed lakes in Peru (L1iboutry and others, 1977).

The most comprehensive description of the failure of a moraine dam is the work of Blown and Church (1985) on the failure of the moraine dam of Nostetuko Lake, British Columbia, Canada (fig. 10). Another valuable account of a moraine-dam failure at Klattasine Lake, British Columbia, sometime between June 1971 and September 1973 was made by Clague and others (1985).

Most of the textural data from moraine dams indicates that the moraine material is silty, sandy, bouldery t $f 11$, with minimal clay (less than 3 or 4 percent). Lake levels are controlled by seepage through the barrier and open overflow channels across the top of the moraine. Of the 14 documented cases of failures of moraine dams known to us, the mechanism of failure is known or can be reasonably estimated for nine. The most common failure mechanism is overtopping by a wave or series of waves generated by icefalls or rockfalls or by snow- or rock-avalanches into the lake basin. The wave overtops the moraine dam, and augmented flow in the outlet channel causes erosion of the channel that permits increased flow from the lake as it begins to drain. Another failure mechanism is overtopping by excessive runoff during glacial retreat, snowmelt, or intense rainfall. The moraine dam impounding Lago Tempanos, Argentina, failed sometime between 1942 and 1953 because of excessive meltwater accompanying a 352 -meter retreat of the glacier (Rabassa and others, 1979). 
Table 5.--Well-documented examples of moraine dams that have failed

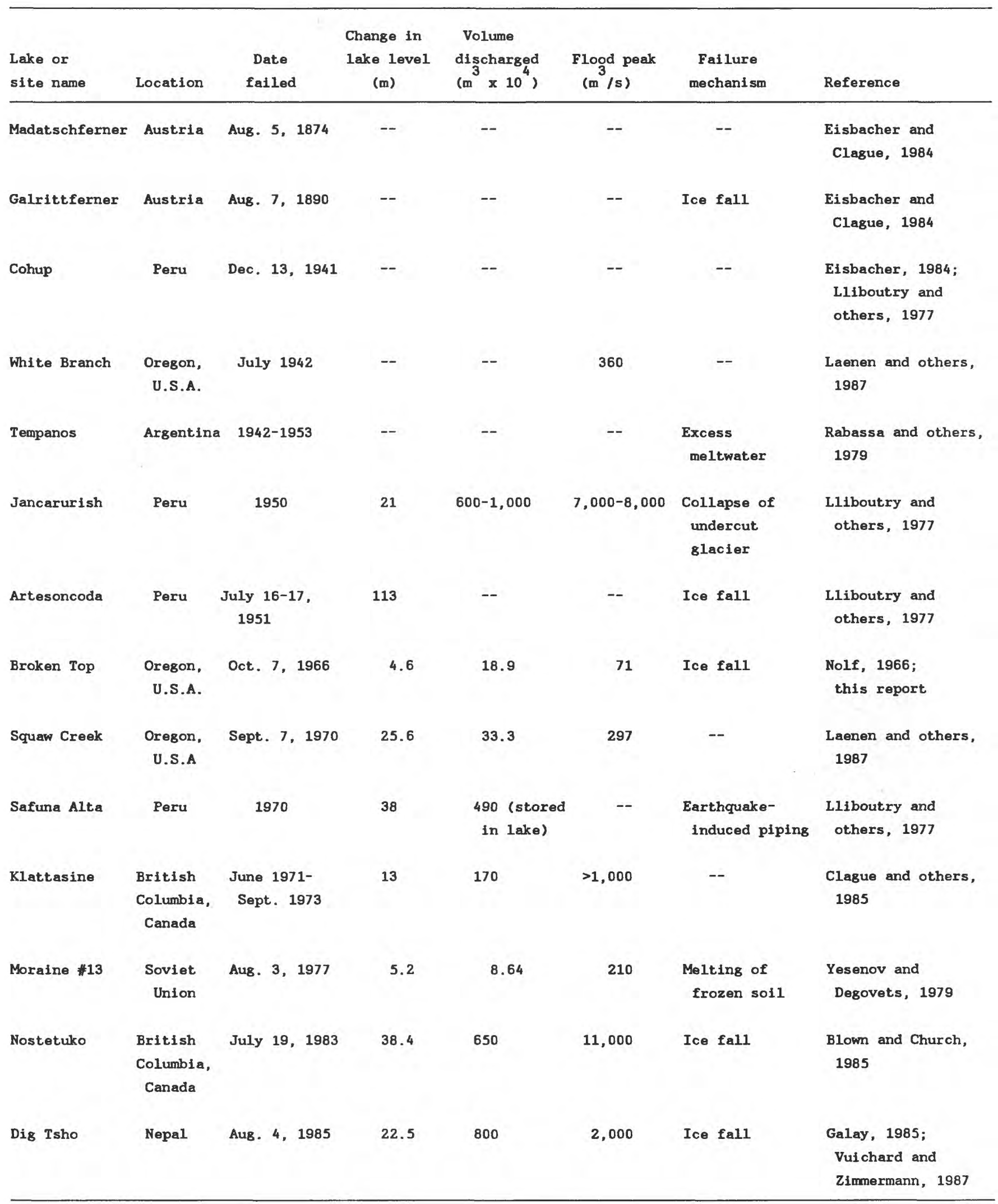




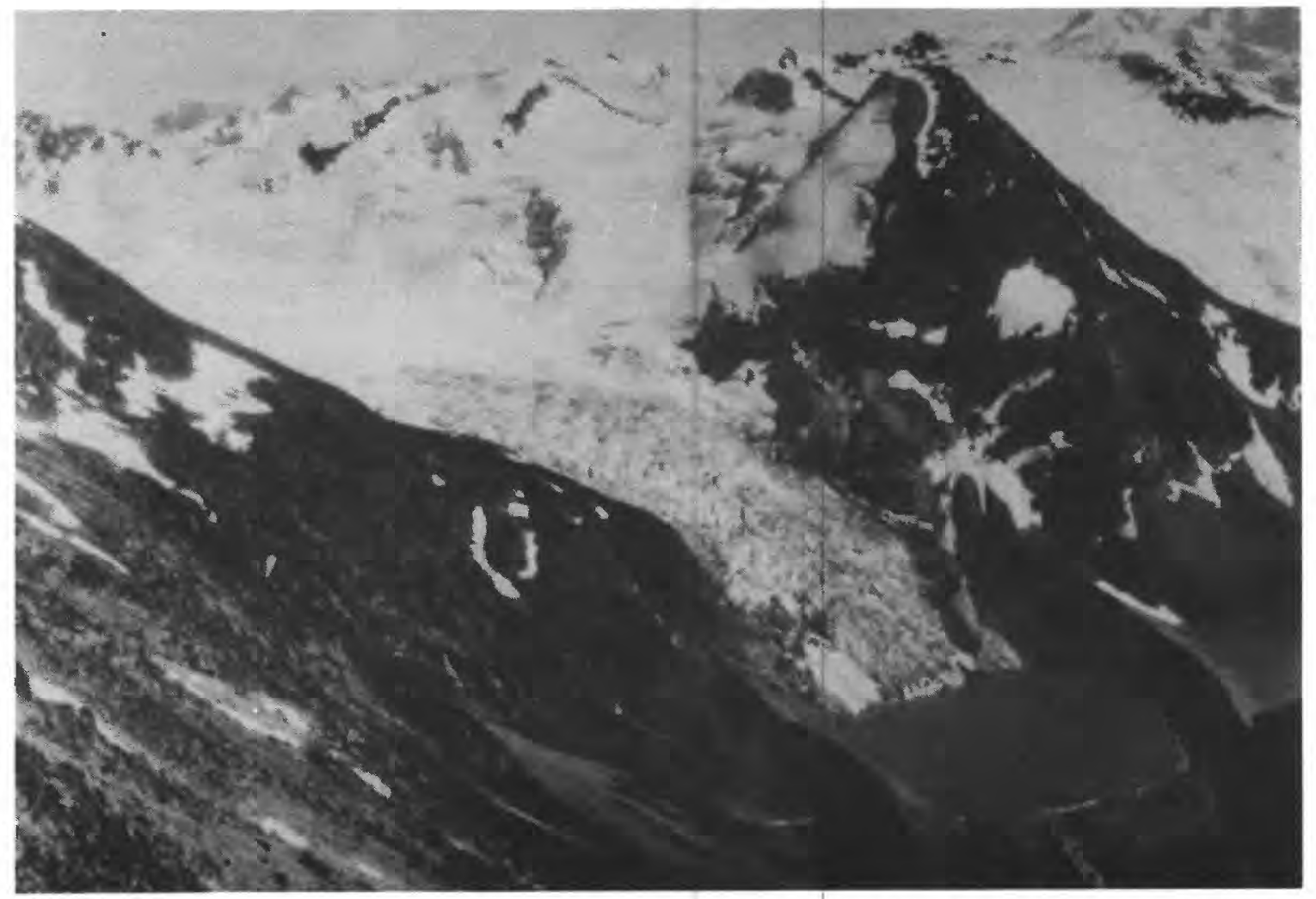

Figure 10-A.--Photograph of Nostetuko Lake, a neoglacial moraine-dammed lake, and Cumberland Glacier, British Columbia, Canada, in July 1977. (Photograph by J. M. Ryder, courtesy of Michael Church, University of British Columbia)

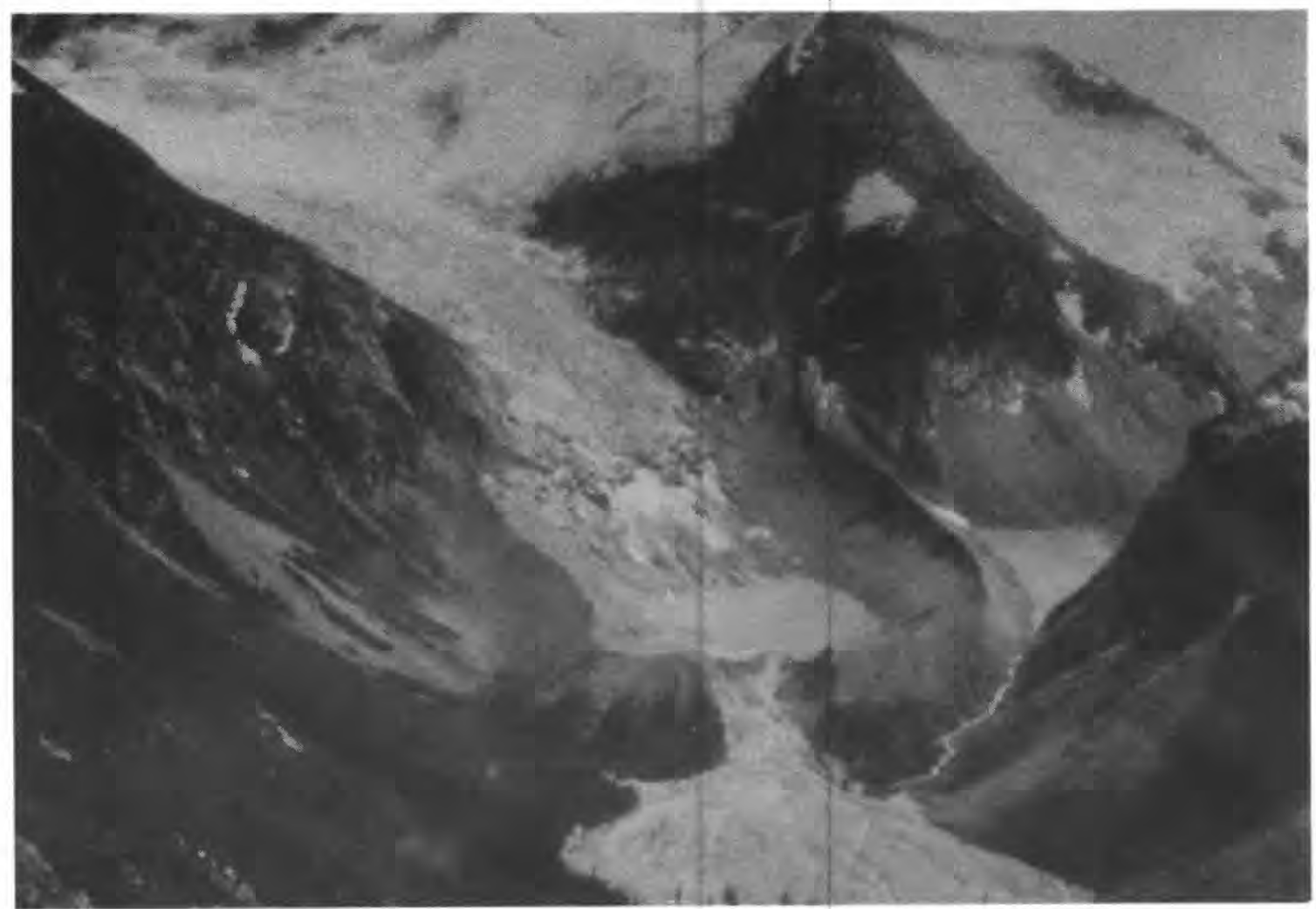

Figure 10-B.--Photograph of Nostetuko Lake and Cumberland Glacier, British Columbia, Canada, in August 1983, after failure of the moraine dam. (Photographs by Michael Church, University of British Columbia) 
In the Cordillera Blanca, Peru, all precisely dated moraine-dam failures occurred during the rainy season from October to April (Lliboutry and others, 1977). Failure during these wet months indicates that increased streamflow is an important factor in moraine-dam failures.

Settlement and subsequent failure of moraine dams accompanying earthquakes is another potential failure mechanism. The large Peruvian earthquake of May 1970 resulted in the release of water from at least two moraine-dammed lakes by piping in the Cordillera Blanca (Lliboutry and others, 1977).

A moraine dam in the Soviet Union collapsed from melting of frozen soil because of high air and water temperatures (Yesenov and Degovets, 1979). Although we know of no documented case, the failure of an icecored moraine dam from ice-melt also is a distinct possibility.

\section{Longevity and Control of Moraine Dams}

The question of the longevity and stability of moraine dams is extremely complex. In our investigations, all of the known moraine dams that failed were late-neoglacial age or younger. Since ice or rock avalanches into moraine-dammed lakes are the primary failure mechanism of moraine dams, lakes located below steep, unstable, and highlycrevassed or fractured glaciers or rock slopes present obvious failure potential. In a study of the hypothetical failure and resulting flood from a late-neoglacial moraine dam in central Oregon, the annual probability of failure was estimated to be 1 to 5 percent because of the instability of the surrounding rock slopes and glacier and the history of previous moraine-dam failures in the area (Laenen and others, 1987). Ice-cored moraines or frozen-soil moraines may thaw for centuries and then become critically unstable (Ostrem, 1964; Andrews, 1975). Once this thaw occurs, the potential for a piping or overtopping failure of the moraine dam increases whenever a period of high runoff occurs.

Artificial controls of the levels of moraine-dammed lakes have been attempted in several locations. The most extensive efforts probably have been undertaken in Peru (Lliboutry and others, 1977). Control efforts include draining of lakes by tunnels through ice and rock, stabilization of lake outlets with paved revetments, increasing freeboard with low earthen dams, and construction of protective retention basins--if valley gradients are sufficiently low (Lliboutry and others, 1977; Yesenov and Degovets, 1979; Eisbacher, 1982).

\section{FLOODS FROM THE FAILURE OF NATURAL DAMS}

Natural dams create the potential for two very different types of flooding: (1) upstream or backwater flooding as the reservoir fills and (2) downstream flooding as a result of failure of the dam.

Upstream flooding occurs because of the relatively slow rise of water behind the dam as the basin of the natural impoundment is filled. The threat of loss of life from this kind of flooding is minimal, but property damage can be substantial as entire developments disappear under water. Upstream-flood damage from glacier and moraine dams generally is not significant because these types of natural dams commonly occur in remote areas where development is minimal. Landslide dams, however, can present significant hazards from backwater flooding. 
Because landslide dams tend to occur in mountainous areas, certain types of structures, such as hydroelectric plants, may be rendered inoperable because of inundation of intakes, flumes, generators, and transportation and transmission facilities (Schuster and Costa, 1986b). A recent example of the consequences of upstream flooding from a landslide dam occurred in April 1983, when a 22-million cubic meter landslide in central Utah dammed the Spanish Fork River and flooded the town of Thistle, Utah (Kaliser and Fleming, 1986; fig. 11).

It usually is possible to accurately estimate the extent and rate of upstream flooding from natural dams. Such estimates require knowledge of height of the dam crest, rates of streamflow or icemelt into the natural reservoir, rates of seepage through or beneath the dam, and information on topography upstream from the dam.

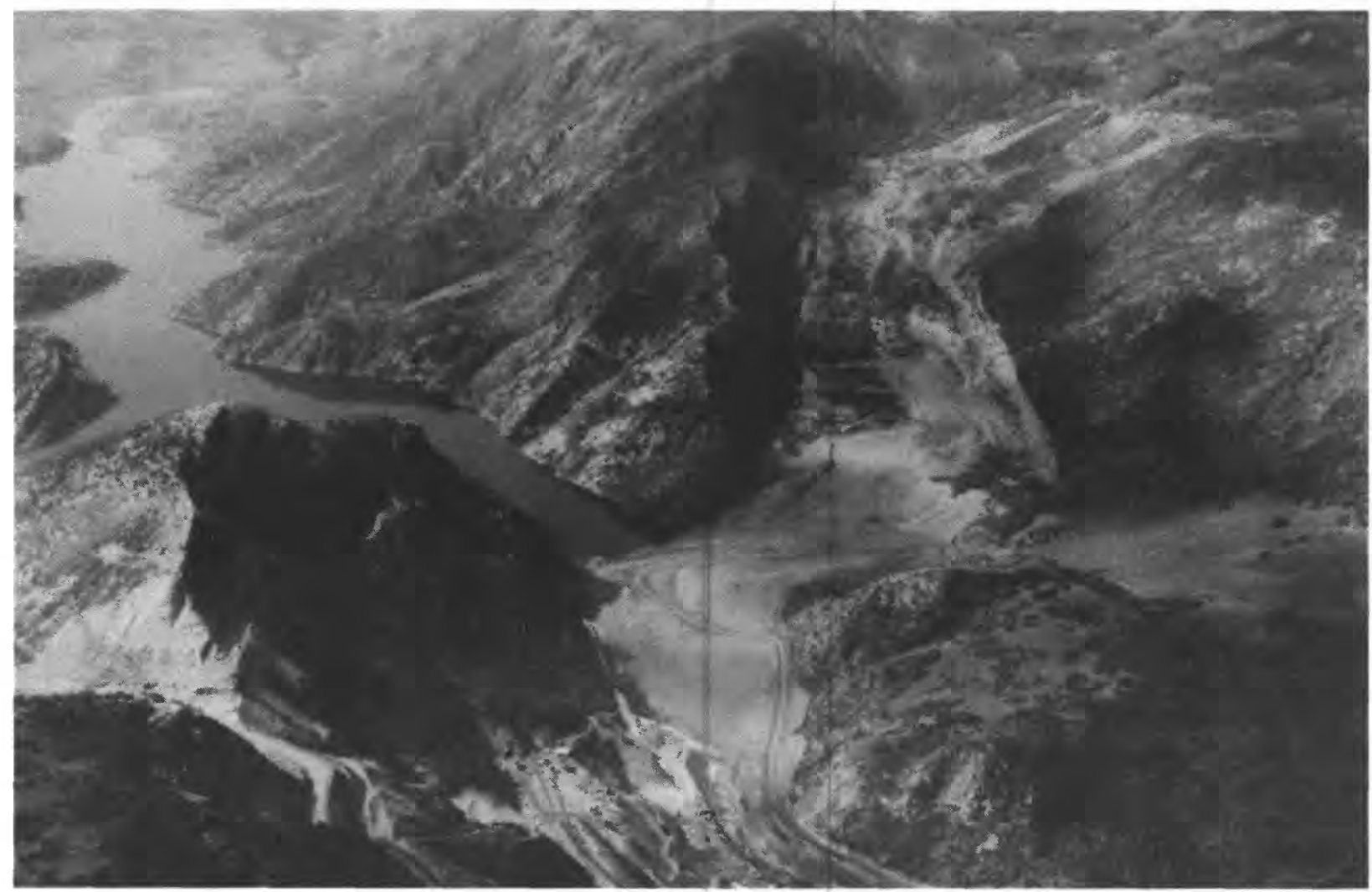

Figure 11.--Photograph of the 1983 landslide at Thistle, Utah, and its temporary impoundment, Thistle Lake, in September 1983. The lake inundated the town of Thistle and was drained late in 1983 by a bedrock tunnel constructed through the mountain at lower left.

\section{Comparison of Floods from the Failure of Different Kinds of Dams}

Floods resulting from the failure of natural dams usually are much larger than floods originating directly from snowmelt or rainfall. Compared with the failure of constructed dams, very little is known about the processes of natural-dam failure. Few accurate data exist about peak discharges, dimensions, or reservoir volumes of failed natural dams (Costa, 1985). 
Many investigations have been conducted on the safety of constructed dams (Jansen, 1980; Committee on the Safety of Existing Dams, 1983), and numerous models have been proposed to determine the outflow hydrograph and downvalley routing of floodwaters resulting from failure of constructed dams (Land, 1980; Fread, 1980). However, few similar evaluations have been made for the failures of natural dams (Ponce and Tsivoglou, 1981; Clarke, 1982), which in many cases are different from those of constructed dams (Costa, 1985).

A dam failure is a complex hydrologic, hydraulic, and geologic phenomenon, controlled primarily by the failure mechanism and characteristics and properties of the dam. One way to compare different kinds of dam failures is to investigate the relationship between the specific energy of the lakewater behind the dam prior to failure and the flood-peak discharge from the failure of the dam (fig. 12). Potential energy of a lake behind a dam can be computed as the product of dam height (meters), volume (cubic meters), and specific weight of water $(9,800$ newtons/cubic meter). Dam-failure flood peak discharges used in figure 12 come from tables 3 and 5 and from Costa (1985).

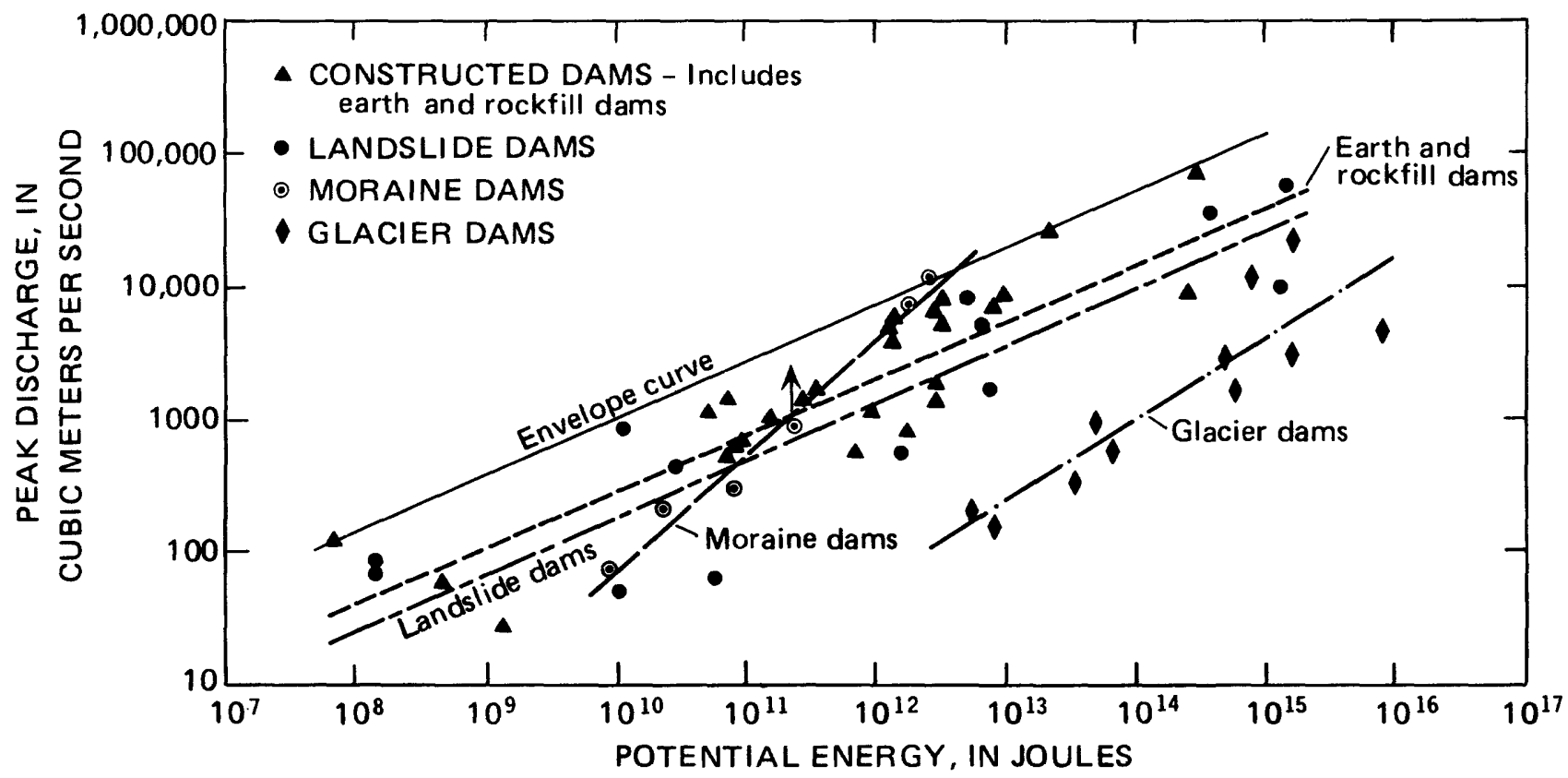

Figure 12.--Graph showing potential energy versus peak discharge for various types of dam failures. Dashed lines are least-squares regression lines for earth- and rock-fill, moraine glacial ice, and landslide dams. Solid line is the envelope curve for all dam-failure data. Data from Costa (1985) and Table 5.

Regression analysis with potential energy as the independent variable produces different equations for landslide, glacier, moraine, and earth- and rock-fill dam-failure flood peaks, with standard errors ranging from 27 percent for moraine dams to 133 percent for landslide dams (table 6). The large scatter in the data in figure 12 reflects the diverse characteristics of individual dams within each category, as well as the difficulty in computing or measuring the peak discharge from a dam failure. Direct measurements of floods are nearly impossible; thus a variety of indirect estimation methods, such as drawdown rates or measurements based on post-flood channel surveys and hydraulic formulas, are used. 
Concern about the large standard errors or overlapping of data from different types of dams is moot, since the variability of individual dam populations is so large and determination of the dependent variable (peak discharge) is so difficult. Individual regressions lines identify different kinds of dams in a physically meaningful way that provides insight into fundamental understanding of natural dams.

Table 6.--Summary of regression equations to predict peak discharge from the failure of earth-and rock-fil1, moraine, glacial-ice, and landslide dams

$$
\left[Q=\text { peak discharge, } \mathrm{m}^{3} / \mathrm{s} ; \mathrm{PE}=\text { potential energy (joules) }\right]
$$

\begin{tabular}{|c|c|c|c|c|}
\hline Type of dam & Equation & $\begin{array}{l}\text { Number of } \\
\text { data points }\end{array}$ & $\begin{array}{l}\text { Coefficient of } \\
\text { determination } \\
\qquad\left(r^{2}\right)\end{array}$ & $\begin{array}{l}\text { Standard } \\
\text { error } \\
\text { (percent) }\end{array}$ \\
\hline $\begin{array}{l}\text { 1. Earth- and } \\
\text { rock-fill }\end{array}$ & $Q=0.0184(P E)^{0.42}$ & 26 & 0.75 & 93 \\
\hline 2. Landslide & $Q=0.0158(\mathrm{PE})^{0.41}$ & 12 & .81 & 133 \\
\hline 3. Moraine & $Q=0.0000069(\mathrm{PE})^{0.73}$ & 3 & .89 & 27 \\
\hline 4. Glacier & $Q=0.0000055(P E)^{0.59}$ & 11 & .80 & 75 \\
\hline
\end{tabular}

For the same potential energy at the time of dam failure, glacier-ice dams produce the smallest peak discharges. For potential energy less than about $10^{11}$ joules, constructed earth- and rock-fill dams produce the largest peak discharges for a constant potential energy. For potential energy greater than about $10^{11}$ joules, moraine-dam failures produce the largest peak discharges for a constant potential energy. Differences in peak discharges for constant potential energy of different kinds of natural and constructed dams originate because of differences in failure mechanisms, which are related to geometry and material characteristics of the dams.

Glacier-dam failures commonly involve the enlargement of subglacial or englacial tunnels during failure. This enlargement requires time and produces relatively small peak discharges compared with other kinds of natural and constructed dams with the same potential energy. Landslide dams are typically much wider than constructed earth-and rock-fill dams and involve much larger volumes of material. The Madison Canyon landslide that dammed the Madison River in 1959, forming Earthquake Lake, had a base width five to eight times as great as would have been used in building a rock-fill dam of the same height (Knight and Bennett, 1960). In figure 13, transverse sections of the Mayunmarca landslide dam in Peru and the Nostetuko moraine dam in British Columbia are compared to the Oroville Dam, a large earth-fill dam in California. The landslide dam in Peru is higher at the abutments and almost as high as the constructed dam in the center, but is over three times as wide. When a landslide dam is overtopped, much more earth material commonly is present for water to erode before a full breach is developed than is the case for constructed embankment dams. This is indicated by the parallel but displaced positions of landslide and earth- and rock-fill dam regression lines shown in figure 12 . 


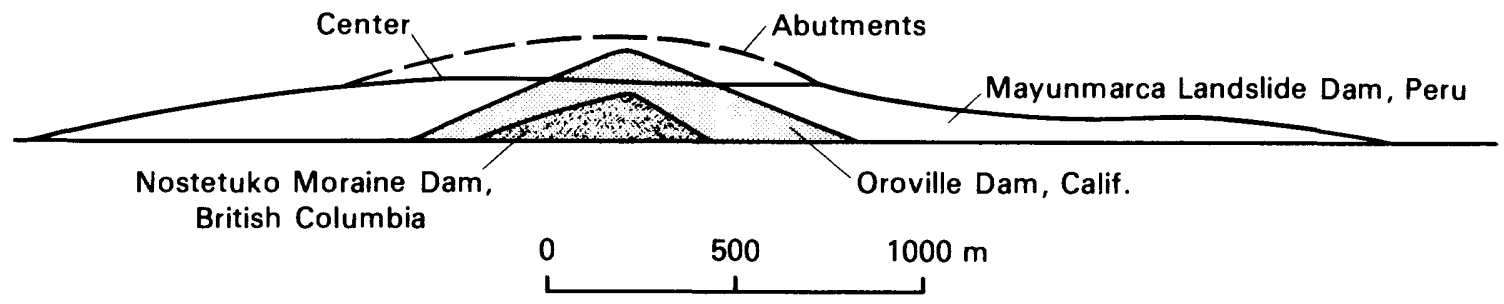

Figure 13.--Diagram showing cross section of Mayunmarca landslide dam, Peru, and Nostetuko moraine dam, British Columbia, compared to the maximum cross section of a large earth-fill dam at Oroville, California. (Modified from Lee and Duncan, 1975)

Moraine dams are relatively high and narrow compared to many landslide dams and have much steeper slopes. The predominate failure mechanism for moraine dams (wave overtopping) leads to rapid erosion of cohesionless sandy and gravelly till comprising many moraine dams. The rapid breach development in moraine-dam failures, compared to other kinds of dams, is primarily responsible for the location of the regression line in figure 12 .

\section{Prediction and Reconstruction of Floods from Dam Failures}

For purposes of rapid prediction when potential loss of life or property is involved, a conservative peak-discharge estimate based on an envelope curve developed from historic failures of landslide, glacier, moraine, and constructed earth- and rock-fill dams can be made from knowledge of the potential energy of the lake behind the dam (fig. 12). The envelope curve that includes data points from all constructed and naturaldam failures for which reasonable estimates of peak discharge exist is defined by the equation

$$
\mathrm{Q}=0.063 \mathrm{PE}^{0.42} \text {, }
$$

where $Q$ is peak discharge, in cubic meters per second, and PE is potential energy, in joules.

For reconstructing past flood peaks from the failure of natural dams for paleohydrological or sedimentological investigations, regression equations for different kinds of natural dams with potential energy as the independent variable could be used (table 6 ).

A complicating factor in downstream routing of floods from natural-dam failures is the bulking and debulking of flood waters with sediment and debris as the flood moves downvalley. The use of envelope curves, regression equations, or dam-break models allows estimation of peak flood discharges at the dam. Most commonly, flood peak discharges attenuate downvalley (Costa, 1985; fig. 8). Sometimes, however, downstream peaks can be considerably larger because easily eroded sediment is added and subtracted from the flow. So much sediment can be added to the flood flow that a debris flow forms. This seems to be an especially important process in volcanic and glacial terrains (Scott, 1985; Yesenov and Degovets, 1979; Clague and others, 1985; Lliboutry and others, 1977). Fluctuations in peak discharge downstream from the failure of a moraine dam on the Kumbel River, U.S.S.R., in 1977 are well documented. Peak discharge from the dam failure was 210 cubic meters per second, but it had bulked to 11,000 cubic meters per second about 15 kilometers downstream (Yesenov and Degovets, 1979). This problem of bulking and debulking presents one of the most difficult unsolved problems in sediment transport today, and its consequences for hazard evaluation are enormous. 


\section{CONCLUSIONS}

Three kinds of natural dams present significant hazards to people and property: landslide dams, glacier dams, and moraine dams. Using a large data base of case studies, significant generalizations about individual kinds of natural dams can be made. Landslide dams form most commonly in steep narrow valleys in geologically active areas, but they have also formed in wide, open stream valleys. Avalanches, slumps and slides, and flows triggered by excessive snowmelt or rainfall or by earthquakes are the most common landslide processes. There are at least six morphologically different kinds of landslide dams, and the danger of failure and flooding varies with the kind of landslide dam.

Based on 73 examples of landslide-dam failures from around the world, landslide dams fail quickly after formation (half fail within 10 days of formation, and 15 percent last more than a year). By far the predominate failure mechanism is overtopping and breaching by headward erosion.

Glacier-dam failures have produced the largest documented historic and prehistoric flood-peak discharges known on Earth. The most dangerous glacier dams are formed when tributary-valley glaciers block main valleys and form large lakes behind them. Temperate glacier dams usually fail by erosion of subglacial or englacial tunnels under or through the ice dam, aided by the hydrostatic pressure of water behind the ice dam. Cold polarice dams fail most commonly by overtopping and erosion of a channel in the ice.

All the documented cases of moraine-dam failures occurred with moraine dams formed in the last few centuries (late neoglacial). The dams originated as dump or ice-thrust moraines and may or may not have ice cores. The predominate failure mechanism is overtopping and rapid erosion by a wave or series of waves generated by rock or ice avalanches into the lake from adjacent steep cirque or valley walls.

For the same potential energy at the dam site, the failures of glacier dams produce the smallest flood peak discharges because of the time required for enlargement of outlet tunnels and channels. For constant potential energy, landslide-dam failures produce smaller flood peaks than failures of constructed earth- and rock-fill dams because of the large volume of material to be eroded before full breach development. For potential energy greater than about $10^{11}$ joules, late-neoglacial moraine dams produce the greatest flood peak discharges of any kind of natural or earth- or rock-fill dam because of rapid breach formation associated with wave overtopping and erosion of non-cohesive till on steep slopes.

An envelope curve defining the maximum discharge produced by the failure of natural and constructed earthen dams can be used as a rapid conservative approximation of the flood peak from the failure of a potentially dangerous natural dam. In areas with abundant looselyconsolidated surficial deposits in stream valleys downstream of natural-dam failures, peak discharges may not attenuate, but could actually increase many times by incorporation of easily erodible sediment and debris. This phenomenon of sediment bulking and debulking downstream from natural-dam failures remains one of the most pressing and difficult unsolved problems in sediment transport today. 


\section{REFERENCES}

Adams, John, 1981, Earthquake-dammed lakes in New Zealand: Geology, v. 9, p. 215-219.

Aitkenhead, N., 1960, Observations on the drainage of a glacier-dammed lake in Norway: Journal of Glaciology, v. 3, p. 607-609.

Alden, W. C., 1928, Landslide and flood at Gros Ventre, Wyoming: American Institute of Mining and Metallurgical Engineers Transactions, v. 76, p. 347-358.

Anderson, G. P., 1948, Waikaremoana--The problem of lake control: Proceedings of the New Zealand Institute of Engineers, v. 34, p. $508-526$.

Andrews, J. T., 1975, Glacial systems: Duxbury Press, North Scituate, Mass., 191 p.

Arnborg, L., 1955, Hydrology of the glacial river Austurfljot: Geografiska Annaler, v. 36, part 3-4, p. 185-201.

Baker, V. R., 1973, Paleohydrology and sedimentology of Lake Missoula flooding in eastern Washington: Geological Society of America Special Paper 144, 79 p.

Ballantyne, C. K., and McCann, S. B., 1980, Short-1ived damming of a high-Arctic ice-marginal stream, E1lesmere Island, N.W.T., Canada: Journal of Glaciology, v. 25, p. 487-491.

Berg, L. S., 1950, Natural regions of the U.S.S.R: New York, MacMillan Co. , $435 \mathrm{p}$.

Blachut, S. P., and Ballantyne, C. K., 1976, Ice-dammed 1akes--A critical review of their nature and behavior: Hamilton, Ontario, McMaster University Department of Geography Discussion Paper No. 6, $90 \mathrm{p}$.

Blown, Iain, and Church, Michael, 1985, Catastrophic lake drainage within the Homathko River basin, British Columbia: Canadian Geotechnical Journal, v. 22, no. 4, p. 551-563.

Bradley, W. C., Fahnestock, R. K., and Rowekamp, E. T., 1972, Coarse sediment transport by flood flows on Knik River, Alaska:

Geological Society of America Bulletin, v. 83, p. 1261-1284.

Budd, W. F., 1975, A first simple model for periodically self-surging glaciers: Journal of Glaciology, v. 14, p. 3-21.

Burgisser, H. M., Gansser, A., and Pika, J., 1982, Late glacial lake sediments of the Indus Valley area, northwestern Himalayas:

Ecologae Geologie Helvetica, v. 75, p. 51-63.

Butler, D. R., Oelfke, J. G., and Oelfke, L. A., 1986, Historic rockfall avalanches, northeastern Glacier National Park, Montana, U.S.A.: Mountain Research and Development, v. 6, p. 1-11.

Chang, Longchian, 1934, Investigation of the Deixi Earthquake, Sichuan: Comments on Geology, The Geological Society of China, Nanking, China, v. 3, no. 3, p. 251-292 [in Chinese]. 
Chang, S. C., 1984, Tsao-Ling landslide and its effect on a reservoir project: Proceedings of IVth International Symposium on Landslides, Toronto, September 16-21, 1984, v. 1, p. 469-473.

Church, Michael, 1972, Baffin Island sandurs--A study of Arctic fluvial processes: Geological Society of Canada Bulletin 216, 208 p.

Clague, J. J., Evans, S. G., and Blown, I. G., 1985, A debris flow triggered by the breaching of a moraine-dammed lake, Klattasine Creek, British Columbia: Canadian Journal of Earth Sciences, v. 22 , p. 1492-1502.

Clague, J. J., and Mathews, W. H., 1973, The magnitude of jokulhlaups: Journal of Glaciology, v. 12, p. 501-504.

Clark, T. H., 1947, Two Recent landslides in Quebec: Transactions of the Royal Society of Canada, v. 41, ser. 3 , sec. 4, p. 9-18.

Clarke, G. K. C., 1982, Glacier outburst floods from "Hazard Lake", Yukon Territory, and the problem of flood magnitude prediction: Journal of Glaciology, v. 28, p. 3-21.

Clarke, G. K. C., Mathews, W. H., and Pack, R. T., 1984, Outburst floods from Glacial Lake Missoula: Quaternary Research, v. 22, p. 289299.

Clarke, G. K. C., and Waldron, D. A., 1984, Simulation of the August 1979 sudden discharge of glacier-dammed Flood Lake, British Columbia: Canadian Journal of Earth Sciences, v. 21, p. 502-504.

Clement, Paul, 1984, The drainage of a marginal ice-dammed lake at Nordbogletscher, Johan Dah1 Land, South Greenland: Arctic and Alpine Research, v. 16, p. 209-216.

Code, J. A., and Sirhindi, Sadiq, 1986, Engineering implications of impoundment of the Indus River by an earthquake-induced landslide, in Shuster, R. L., ed., Landslide dams: Processes, Risk, and migitation: American Society of Civil Engineers, Geotechnical Special Publication no. 3, p. 97-110.

Committee on the Safety of Existing Dams, 1983, Safety of existing dams, evaluation and improvement: Washington, D. C., National Academy Press, $354 \mathrm{p}$.

Costa, J. E., 1985, Floods from dam failures: U.S. Geological Survey Open-File Report 85-560, 54 p.

Cotecchia, V., 1978, Systematic reconnaissance mapping and registration of slope movements: Bulletin of the International Association of Engineering Geology, v. 17, p. 5-37.

Cotton, C. A., 1941, Landscape, as developed by the processes of normal erosion: New York, John Wiley and Sons, Inc., 509 p.

Crande11, D. R., and Varnes, D. J., 1961, Movement of the Slumgullion earthflow near Lake City, Colorado: U.S. Geological Survey Professional Paper 424-B, p. B-136 to B-139.

Davis, W. M., 1882, On the classification of lake basins: Proceedings, Boston Society of Natural History, v. 21, p. 315-381. 
Davis, W. M., 1933, The lakes of California: California Journal of Mines and Geology, v. 29, p. 175-236.

Dawson, G. M., 1898, Remarkable landslip in Portneuf County, Quebec: Geological Society of America Bulletin. v. 10, p. 484-490.

Eden, W. J., Fletcher, E. B., and Mitche11, R. J., 1971, South Nation River landslide, 16 May 1971: Canadian Geotechnical Journal, v. 8, p. 446-451.

Eisbacher, G. H., 1982, Mountain torrents and debris flows: Episodes, v. 1982, no. 4, p. 12-17.

Eisbacher, G. H., and Clague, J. J., 1984, Destructive mass movements in high mountains--Hazard and management: Geological Survey of Canada Paper 84-16, $230 \mathrm{p}$.

Emerson, F. B., 1925, 180-ft. dam formed by landslide in Gros Ventre Canyon: Engineering News-Record, v. 95, no. 12, p. 467-468.

Ericksen, G. E., Plafker, George, and Concha, J. F., 1970, Preliminary report on the geologic events associated with the May 31, 1970, Peru earthquake: U.S. Geological Survey Circular 639, 25 p.

Evans, S. G., 1984, The 1880 landslide dam on Thompson River near Ashcroft, British Columbia, in Current Research: Part A, Geological Survey of Canada, Paper 84-1A, p. 655-658.

Evans, S. G., 1986, Landslide damming in the Cordillera of western Canada in Schuster, R. L., ed., Landslide dams--Processes, risk, and mitigation: American Society of Civil Engineers, Geotechnical Special Pub1ication no. 3, p. 111-130.

Finch, R. H., 1937, A tree-ring calendar for dating volcanic events, Cinder Cone, Lassen Nationa1 Park, California: American Journal of Science, v. 33, p. 140-146.

Fread, D. L., 1980, DAMBRK--The NWS dam-break flood forcasting model: Silver Spring, Maryland, National Weather Service, Office of Hydrology, Office of Hydrology, $37 \mathrm{p}$.

Fread, D. L., 1985, BREACH--An erosion model for earthen dam failures: Silver Spring, Maryland, National Weather Service, 29 p.

Galay, V. J., 1985, Hindu Kush-Himalayan erosion and sedimentation in relation to dams: International Workshop on Water Management in the Hindu Kush-Himalaya region, Chengdu, China, Chinese Academy of Science, $24 \mathrm{p}$.

Gallino, G. L., and Pierson, T. C., 1985, Polallie Creek debris flow and subsequent dam-break flood of 1980, East Fork Hood River basin, Oregon, U.S. Geological Survey Water Supply Paper 2273, 22 p.

Gaziev, E., 1984, Study of the Usoy landslide in Pamir: Proceedings of the IVth International Symposium on Landslides, Toronto, September $16-21,1984$, v. 1, p. 511-515.

Gilbert, G. K., 1878, The ancient outlet of Great Salt Lake: American Journal of Science, v. 15, p. 256-259. 
Gilbert, R., 1971, Observations on ice-dammed Summit Lake, British Columbia, Canada: Journal of Glaciology, v. 10, p. 351-356.

Glazyrin, G. Ye., Reyzvikh, V. N., 1968, Computation of the flow hydrograph for the breach of landslide lakes: Soviet Hydrology, no. 5, p. 592-596.

Grove, J. M., 1979, The glacial history of the Holocene: Progress in Physical Geography, v. 3, p. 1-54.

Gunn, J. P., 1930, The Shyok flood, 1929: The Himalayan Journal, v. 2, p. $35-47$.

Hadley, J. B., 1964, Landslides and related phenomena accompanying the Hebgen Lake earthquake of August 17, 1959: U.S. Geological Survey Professional Paper 435, p. 107-138.

Haeberli, Wilfried, 1983, Frequency and characteristics of glacier floods in the Swiss Alps: Annals of Glaciology, v. 4, p. 85-90.

Hagen, V. K., 1982, Re-evaluation of design floods and dam safety: Paper presented at 14th International Commission on Large Dams Congress, Rio de Janeiro.

Harp, E. L., Wilson, R. C., and Wieczorek, G. F., 1981, Landslides from the February 4, 1976, Guatemala earthquake: U.S. Geological Survey Professional Paper 1204-A, 35 p.

Harrison, A., 1974, Madison Canyon slide mass modification by the U.S. Army Corps of Engineers, in Voight, Barry, ed., Rock Mechanics--The American Northwest: Third International Congress on Rock Mechanics, International Society for Rock Mechanics, Pennsylvania State University College of Earth Sciences Experiment Station Special Publication, p. 138-143.

Hewitt, Kenneth, 1982, Natural dams and outburst floods of the Karakoram Himalaya, in Glen, J. W., ed., Hydrological aspects of alpine and high-mountain areas: International Association of Hydrological Sciences Publication 138, p. 259-269.

Holmes, Arthur, 1965, Principles of physical geology, 2nd ed.: New York, Ronald Press Co., 1288 p.

Hutchinson, G. E., 1957, A treatise on limnology, Volume 1: New York, John Wiley \& Sons, $1015 \mathrm{p}$.

Hutchinson, J. N., and Kojan, E., 1975, The Mayunmarca lands1ide of 25 April 1974: UNESCO Serial No. 3124/RHO. RD/SCE, Paris, 23 p.

Jansen, R. B., 1980, Dams and public safety: U.S. Department of the Interior, Bureau of Reclamation, Denver, Colorado, 332 p.

Jones, D. P., Ricker, K. E., Desloges, J. R., and Maxwe11, Michael, 1985, Glacier outburst flood on the Noelck River--The draining of Ape Lake, British Columbia, October 20, 1984: Geological Survey of Canada Open-File Report 1139, 81 p. 
Kaliser, B. N., and Fleming, R. W., 1986, The 1983 landslide dam at Thistle, Utah, in Schuster, R. L., ed., Landslide dams: Processes, risk, and mitigation: American Society of Civil Engineers, Geotechnical Special Publication No. 3, p. 59-83.

King, J. P., 1986, Investigation into the damming of the Bairaman River after the earthquake of 11 May 1985, West New Britain Province: Geological Survey of Papua, New Guinea, File E5080, 17 p. plus appendices.

King, W. D. V. O., 1934, The Mendoza River flood of 10-11 January 1934, Argentina: Geographical Journal, v. 84, p. 321-326.

Laenen, Antonius, Scott, K. M., Costa, J. E., and Orzol, L. L., 1987 , Hydrologic hazards along Squaw Creek from a hypothetical failure of teh glacial moraine impounding Carver Lake near Sisters, Oregon: U.S. Geological Survey Open-File Report 87-41, 48 p.

Knight, D. K., and Bennett, P. T., 1960, Stability of slide dam and recommendations on development of overflow spillway, in Madison River, Montana, Report on flood emergency, Madison River slide: Appendix VI, U.S. Army Corps of Engineers, Riverdale, North Dakota, $5 \mathrm{p}$.

Land, L. F., 1980, Evaluation of selected dam-break floodway models by using field data: U.S. Geological Survey Water-Resources Investigations Report 80-44, 54 p.

Lee, K. L., and Duncan, J. M., 1975, Landslide of April 25, 1974, on the Mantaro River, Peru: Committee on Natural Disasters, Commission on Sociotechnical Systems, National Research Council, Washington, D. C., $72 \mathrm{p}$.

Li Gong-Shou and $\mathrm{Hu} \mathrm{Tie}-\mathrm{Fu}, 1982$, The activity and taming of Zhouqu landslide-earthflow: Landslides and mudflows, A. Sheko, ed., Reports of Alma-Ata International Seminar, October 1981, Centre of International Projects, GKNT, Moscow, U.S.S.R., p. 466-472.

Li Tianchi, Schuster, R. L., and Wu Jishan, 1986, Landslide dams in south-central China, in Schuster, R. S., ed., Landslide dams-Processes, risk, and mitigation: American Society of Civil Engineers Geotechnical Special Publication No. 3, p. 146-162.

Lliboutry, Louis, Arnao, B. M., Pautre, Andre, and Schneider, Bernard, 1977, Glaciological problems set by the control of dangerous lakes in Cordillera Blanca, Peru. I. Historical failures of morainic dams, Their causes and prevention: Journal of Glaciology, v. 18, p. 239-254.

Maag, H. V., 1969, Ice-dammed lakes and marginal glacial drainage on Axel Heiberg Island: Axel Heiberg Island Research Report, McGill University, Montreal, $147 \mathrm{p}$.

Malde, H. E., 1968, The catastrophic Late Pleistocene Bonneville flood in the Snake River plain, Idaho: U.S. Geological Survey Professional paper 596, $52 \mathrm{p}$.

Marcus, M. G., 1960, Periodic drainage of glacier-dammed Tulsequah Lake, British Columbia: Geographical Review, v. 50, p. 89-106. 
Marr, J. E., 1916, The geology of the Lake District and the scenery as influenced by geological structure: Cambridge University Press, $220 \mathrm{p}$.

Mason, Kenneth, 1929, Indus floods and Shyok glaciers: The Himalayan Journal, v. 1, p. 10-29.

Mathews, W. H., 1965, Two self-dumping ice-dammed lakes in British Columbia: Geographical Review, v. 55, p. 46-52.

Mathews, W. H., 1973, Record of two jokulhlaups: International Association of Scientific Hydrology Publication 95, p. 99-110.

Matthes, F. E., 1939, Report of Committee on Glaciers: Transactions, American Geophyscial Union, v. 20, p. 518-523.

Meier, M. A., and Post, Austin, 1969, What are glacier surges?: Canadian Journal of Earth Science, v. 6, p. 807-817.

Meyer, W., Sabol, M. A., and Schuster, R. L., 1986, Landslide dammed lakes at Mount St. Helens, Washington, in Schuster, R. L., ed., Landslide dams--Processes, risk, and mitigation: American Society of Civil Engineers Geotechnical Special Publication No. 3, p. 21 41.

Nash, D. F. T., Brunsden, D. K., Hughes, R. E., Jones, D. K. C., and Whalley, B. F., 1985, A catastrophic debris flow near Gupis, northern areas, Pakistan: Proceedings of the Eleventh International Conference on Soil Mechanics and Foundation Engineering, San Francisco, 12-16 August 1985, v. 3, p. 1163-1166.

Nichols, R. L., and Miller, M. M., 1952, The Moreno Glacier, Lago Argentino, Patagonia, Advancing glaciers and nearby simultaneously retreating glaciers: Journal of Glaciology, v. 2, p. 41-50.

Nolf, Bruce, 1966, Broken Top breaks--Flood released by erosion of glacial moraine: The Ore Bin, v. 28, no. 10, p. 182-188.

Nye, J. F., 1976, Water flow in glaciers--Jokulhlaups, tunnels, and veins: Journal of Glaciology, v. 17, p. 181-207.

01tman, R. E., 1968, Reconnaissance investigations of the discharge and water quality of the Amazon River: U.S. Geological Survey Circular $552,16 \mathrm{p}$.

Ostrem, G., 1964, Ice-cored moraines in Scandinavia: Geografiska Annaler, v. 46, p. 282-337.

Ousley, Ralph, 1788, An account of the moving of a bog, and the formation of a lake, in the county of Galway, Ireland: Transactions of the Royal Irish Academy, v. 2, p. 3-5.

Petrascheck, A. W., and Sydler, P. A., 1984, Routing of dam break floods: International Water Power and Dam Construction, v. 36, p. $29-32$.

Ponce, V. M., and Tsivoglou, A. J., 1981, Modeling gradual dam breaches: Journal of the Hydraulics Division, American Society of Civil Engineers, v. 106, no. HY7, p. 829-838. 
Porter, S. C., and Denton, G. H., 1967, Chronology of neoglaciation in the North American Cordillera: American Journal of Science, $v$. 267 , p. 177-210.

Post, Austin, and Mayo, L. R., 1971, Glacier dammed lakes and outburst floods in Alaska: U.S. Geological Survey Hydrologic Investigations Atlas HA-455, $10 \mathrm{p}$.

Pushkarenko, V. P., 1982, Regularities of mud-rock flow formation in central Asia, in A. Sheko, ed., Landslides and mudflows: Reports of Alma-Ata International Seminar, Alma-Ata, U.S.S.R., October 1981, Centre of International Projects, GKNT, Moscow, p. 87-106.

Rabassa, Jorge, Rubulis, S., and Suarez, J., 1979, Rate of formation and sedimentology of (1976-1978) push-moraines, Frias Glacier, Mount Tronadoz ( $\left.41^{\circ} 10^{\prime} \mathrm{S} ; 71^{\circ} 53^{\prime} \mathrm{W}\right)$, Argentina, in Schluchter, Ch., ed., Moraines and varves: Rotterdam, A. A. Balkema, p. 65-79.

Richardson, Donald, 1968, Glacier outburst floods in the Pacific Northwest: U.S. Geological Survey Professional Paper 600-D., p. D79-D86.

Russe11, I. C., 1893, A geological reconnaissance in central Washington: U.S. Geological Survey Bulletin 108, 168 p.

Sager, J. W., and Chambers, D. R., 1986, Design and construction of the Spirit Lake outlet tunnel, Mount St. Helens, Washington, in Schuster, R. L., ed., Landslide dams--Processes, risk, and mitigation: American Society of Civil Engineers Geotechnical Special Publication No. 3, p. 42-58.

Schuster, R. L., 1985, Landslide dams in the western United States: IVth International Conference and Field Workshop on Landslides, Tokyo 1985, Proceedings, p. 411-418.

Schuster, R. L., and Costa, J. E., 1986a, A perspective on landslide dams, in Schuster, R. L., ed., Landslide dams--Processes, risk, and mitigation: American Society of Civil Engineers Geotechnical Specia1 Publication No. 3, p. 1-20.

Schuster, R. L., and Costa, J. E., 1986b, Effects of landslide damming on hydroelectric projects: Proceedings, Vth International Congress of the International Association of Engineering Geology, Buenos Aires, v. 4, p. 1295-1307.

Scott, K. M., 1986, Lahars and lahar-runout flows in the Toutle-Cowlitz River system, Mount St. Helens, Washington--Origins, behavior, and sedimentology: U.S. Geological Survey Open-File Report 85-500, 202 p.

Scott, W. E., Meloy, W. D., Shroba, R. R., and Miller, R. D., 1980, New interpretations of the Late Quaternary history of Lake Bonneville, western United States: American Quaternary Association Abstracts with Programs, v. 6, p. 168.

Sherard, J. L., 1979, Sinkholes in dams of coarse, broadly grained soils: Transactions, 13th International Congress on Large Dams, New Delhi, India, v. 2, p. 25-35. 
Silva, L., Cocheme, J. J., Canal, R., Ouffield, W. A., and Tilling, R. I., 1982, The March-April 1982 eruptions of Chichonal Volcano, Chiapas, Mexico--Preliminary observations: (abstract) EOS, v. 63, p. 1126 .

Snow, D. T., 1964, Landslide of Cerro Condor-Sencca, Department of Ayacucho, Peru, in G. A. Kiersch, ed., Engineering geology case histories: Geological Society of America, no. 5, p. 1-6.

Stone, K. H., 1963, The annual emptying of Lake George, Alaska: Arctic, v. 16, p. $26-40$.

Sturm, Matthew, and Benson, C. S., 1985, A history of jokulhlaups from Strandline Lake, Alaska, U.S.A.: Journal of Glaciology, v. 31, p. $272-280$.

Sugden, D. E., Clapperton, C. M., and Knight, P. G., 1985, A jokulhlaup near Sondre Stronfjord, West Greenland, and some effects on the ice-sheet margin: Journal of Glaciology, v. 31, p. 366-368.

Swanson, F. J., Oyagi, Norio, and Tominaga, Masaki, 1986, Lands1ide dams in Japan, in Schuster, R. L., ed., Landslide dams--Processes, risk, and mitigation: American Society of Civil Engineers Geotechnical Special Publication No. 3, p. 131-145.

Swanson, F. J., Graham, R. L., and Grant, G. E., 1985, Some effects of slope movements on river channels, in International Symposium on Erosion, Debris Flow, and Disaster Prevention, Proceedings: Tsukuba, Japan, Erosion Control Engineering Society of Japan, p. $273-278$.

Thorarinsson, Sigurdur, 1939, The ice-dammed lakes of Iceland with particular reference to their value as indicators of glacial oscillations: Geografiska Annaler, v. 21, no. 3-4, p. 216-242.

, 1953, Some new aspects of the Grimsvotn problem: Journal of Glaciology, v. 2, p. 267-275.

, 1957, The jokulhlaup from the Katla area in 1955 compared with other jokulhlaups in Iceland: Reykjavik, Museum of National History Miscellaneous Papers No. 18, p. 21-25.

Tufue11, Lance, 1984, Glacier hazards: London, Longman, 97 p.

U.S. Bureau of Reclamation, 1974, Design of smal1 dams: United States Department of the Interior, United States Government Printing Office, Washington, D. C., Second Edition, 816 p.

Varnes, D. J., 1978, Slope movement types and processes, in Schuster, R. L. and Krizek R. J., eds., Landslides-Analysis and control: Transportation Research Board Special Report 176, National Academy of Sciences, Washington, D. C., P. 11-33.

Vuichard, Danie1, and Zimmerman, Markus, 1987, The 1985 catastrophic drainage of a moraine-dammed lake, Khumbu Himal: Cause and consequences: Mountain Research and Development, v. 7, p. 91-110.

Whalley, W. B., 1971, Observations of the drainage of an ice-dammed lake--Strupvatnet, Troms, Norway: Norsk Geografisk Tidsekritt, v. 25 , part 3-4, p. 165-174. 
Yesenov, U. Y., and Degovets, A. S., 1979, Catastrophic mudflow on the Bol'shaya Almatinka River in 1977: Soviet Hydrology, v. 18, p. $158-160$.

Young, G. J., 1980, Monitoring glacier outburst floods: Nordic Hydrology, v. 11, p. 285-300. 